\title{
Influence of soil on groundwater geochemistry in a carbonate aquifer, southern Italy
}

\author{
Tiziano Boschetti ${ }^{1}$, Antonio Falasca ${ }^{2}$, Antonio Bucci ${ }^{2}$, Vincenzo De Felice ${ }^{2}$, \\ Gino Naclerio ${ }^{2}$, and Fulvio Celico ${ }^{1 *}$ \\ ${ }^{1}$ Department of Physics and Earth Sciences "Macedonio Melloni”, University of Parma, Parco Area delle Scienze 157/A, 43124 Parma, Italy \\ ${ }^{2}$ Department of Biosciences and Territory, University of Molise, Contrada Fonte Lappone, 86090 Pesche (IS), Italy
}

\begin{abstract}
The role of soil compositions in influencing groundwater geochemistry in carbonate aquifers is still little known. Nothing is known regarding the influence of pyroclastic soils (andisol) within the carbonate Apennines in central-southern Italy, despite their wide distribution. In this study we analyze some physical and chemical properties of pyroclastic soil at the Acqua dei Faggi experimental site (southern Italy), to assess its influence on groundwater geochemistry. Chemical analyses were carried out on saturated paste extracts and a physical analogue model was developed through two column experiments. Physico-chemical properties of rainwater and spring water, and some microbiological features of the soil medium were also taken into consideration.

The studied soil has a great influence in modifying rainwater chemistry during percolation. About the $50 \%$ of $\mathrm{HCO}_{3}^{-}$and $\mathrm{Ca}^{2+}$ in spring water is due to interaction between percolation water and soil medium, and equilibrium with calcite is reached at this stage. The $\mathrm{Na}^{+} / \mathrm{K}^{+}$ratio is buffered by clay minerals in the soil by primary silicates in the pyroclastic cover. $\mathrm{Cl}^{-}$and $\mathrm{SO}_{4}{ }^{2-}$ concentrations in spring water are very close to that of soil infiltration water during short-term interaction with soil, but a decline is showed during long-term cause to the anions adsorption effect in the andisol. Chemical and microbiological investigations show the existence of a soil microbial community that allows denitrification and nitrate reduction. Infiltration processes cause anoxic conditions within the soil medium, therefore the absence of $\mathrm{NH}_{4}{ }^{+}$in spring water throughout the observation period should be due to anammox processes. These findings suggest that hydrochemistry and spring chemographs may be significantly influenced by several factors, such as relationships between soil and rainwater, vegetation, and microbial communities, which are not necessarily correlated with lithological and structural features of carbonate aquifers.
\end{abstract}

Keywords: $\quad$ carbonate aquifer; groundwater geochemistry; microbial processes; pyroclastic soil; soil chemistry Received 23 July 2013; Revised 5 February; Accepted 6 February 2014

Citation: $\quad$ Boschetti T., Falasca A., Bucci A., De Felice, V., Naclerio, G. and Celico F. 2014. Influence of soil on groundwater geochemistry in a carbonate aquifer, southern Italy. International Journal of Speleology, 43 (1), 79-94. Tampa, FL (USA) ISSN 0392-6672

http://dx.doi.org/10.5038/1827-806X.43.1.8

\section{INTRODUCTION}

Relatively little is known regarding the role of soil compositions in influencing groundwater geochemistry in carbonate aquifers (e.g., Tooth \& Fairchild, 2003; Musgrove \& Bunner, 2004), with emphasis on Italian settings. Nothing is known regarding the influence of pyroclastic soils within the carbonate Apennines in central-southern Italy, despite their wide distribution. Yet, the influence of soils may be of particular relevance in such carbonate environments due to rapid water infiltration and flow through the carbonate rocks, and the diffuse interaction between infiltration water and pyroclastic soil (Celico et al., 2004; Allocca et al., 2008; Naclerio et al., 2008). In the wider context of the whole Italian carbonate Apennines, soil of different origin can play an important role in influencing some hydrochemical features, as hypothesized in some studies (e.g., Tallini et al., 2005).

The role of soil on groundwater geochemistry is governed not only by soil composition but also by grain size distribution and hydraulic features of soils. For example, in south eastern Australia Bennetts et al. (2006) and Edwards \& Webb (2006) found that infiltration water that percolates rapidly through thin and permeable soils retains a rainfall-like chemical signature, while infiltration water that percolates 
slowly through a clay-rich soil has its chemistry significantly modified with respect to rainwater.

This is different from carbonate aquifers, within the Italian Apennines, where the topsoil has a different origin.

With regard to soils formed in volcanic ejecta, it is known that they contain a large accumulation of organic carbon, whose preservation results from burial of soils by repeated addition of volcanic ash, chemical interactions with non-crystalline inorganic materials and physical protection from microaggregation that these materials impart to the soil structure (Eswaran et al., 1993). Microbial mineralization of such organic carbon produces $\mathrm{CO}_{2}$, therefore enhancing carbonate dissolution in the limestone bedrock after percolation through the pyroclastic cover. Within the carbonate Apennines oxidation processes of organic carbon are enhanced by application of fresh manure for agricultural purposes in karstic depressions, and by spreading of fecal matter in pasture areas. In woodland, the existence of deciduous species instead of coniferous ones further enhances $\mathrm{CO}_{2}$ production through root respiration (Raich \& Schlesinger, 1992; Risk et al., 2002), thus promoting karstification in a wide portion of the Apennines (Celico et al., 2010).

The main scope of this study was to analyze some physical and chemical properties of the pyroclastic soil at the Acqua dei Faggi experimental site (southern Italy), to assess its influence on groundwater geochemistry. Physico-chemical properties of rainwater and spring water, and some microbiological features of the soil medium were also taken into consideration.

\section{DESCRIPTION OF THE FIELD SITE}

The Acqua dei Faggi experimental site at Longano in the Molise region (Fig. 1) consists mainly of limestone, and subordinately of marly limestone and marls (Monte Calvello Formation, Cretaceous-Oligocene; Pescatore, 1963). The aquifer boundaries are lowpermeability fault zones that compartmentalize the aquifer system. However, some tectonic discontinuities allow significant groundwater flowthrough, and interdependence of hydraulic heads upgradient and downgradient of these faults has been observed (Celico et al., 2006). The aquifer behaves as a basinin-series system, where seasonal springs occur along some fault zones (Celico et al., 2006). Temporary springs may flow depending on relationships between low-permeability fault cores and karst conduits, that locally interrupt the low-permeability barrier (Petrella et al., 2009a). At basin scale, the groundwater flows westwards towards the perennial spring (Fig. 1). All springs are characterized by irregular hydrographs. The discharges go from a few to some hundreds litres per second.

The carbonate medium is laterally and vertically well connected in the subsurface and the fracture spacing is sufficiently dense to apply the continuum approach to describe groundwater flow at the metric scale (Petrella et al., 2007). A significant vertical heterogeneity of the carbonate bedrock has been found, due to differences in fissuring and karstification with depth. The epikarst is made up of two horizons. An upper part diffusely karstified, which lies below pyroclastic soil, and a lower part subordinately karstified (Petrella et al., 2007; Celico et al., 2010). Darcy's law can be applied in this epikarst portion, and groundwater flow is expected to be laminar also in the upper epikarst and in the underlying fractured bedrock (Petrella et al., 2008). The longitudinal dispersivity calculated (Petrella et al., 2008) in the upper epikarst at the metric scale $(2.42 \mathrm{~m})$ shows variations in the velocity field in the direction of flow typical of carbonate systems at the same experiment scale (Schulze-Makuch, 2005). Differently, the longitudinal dispersivity in the lower epikarst $(0.13 \mathrm{~m})$ is typical of other consolidated rocks, such as sandstones, basalts and granites. These findings further support that, on the whole, the studied carbonate aquifer behaves mainly as a fractured medium.

The hydraulic head responds rapidly to recharge events, due to fast and diffuse rainwater infiltration. The permeability contrast at the base of the epikarst is not large enough to cause significant retention of percolation and water storage in a temporary perched aquifer during rainwater infiltration. Thus, any funneling in larger shafts significantly influences the aquifer behaviour (Petrella et al., 2007), and the

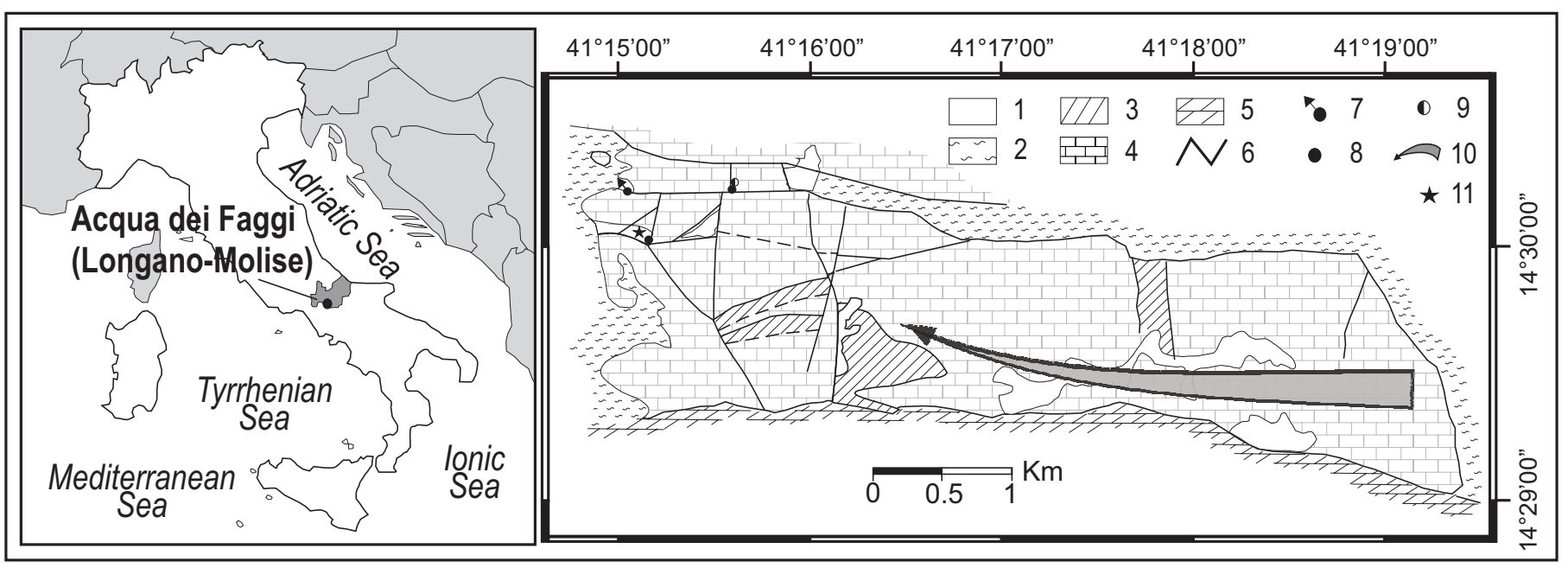

Fig. 1. Hydrogeological map (1 quaternary deposits; 2 marls and clays; 3 marls and marly limestone; 4 limestone; 5 dolostone; 6 fault; 7 perennial spring; 8 seasonal springs; 9 temporary spring; 10 main groundwater flow direction; 11 rainwater sampler [RWS2]). 
aquifer is diffusely recharged by rainwater infiltration (Petrella et al., 2009b; Petrella \& Celico, 2013).

Carbonates generally lie below a soil of pyroclastic origin (Celico et al., 2004) that can be classified as Vitric Andosol (as defined by FAO, 1988). The soil is characterized by (Naclerio et al., 2008) high organicmatter content $(20 \%$ to $35 \%)$, fibrous structure, specific-gravity values ranging from $2.1 \mathrm{~g} / \mathrm{cm}^{3}$ to 2.4 $\mathrm{g} / \mathrm{cm}^{3}$, uniformity coefficient ranging between 3 and 9 , and a prevailing sandy loam texture (as defined by the US Department of Agriculture, 1979). The hydraulic conductivity ranges between $6.5 \cdot 10^{-6}$ and $6.3 \cdot 10^{-5} \mathrm{~m} / \mathrm{s}$ (Naclerio et al., 2009a, 2009b) allowing a diffuse and rapid rainwater percolation.

Pasture areas cover $55 \%$ of the site, while a deciduous beech woodland (Fagus sylvatica L.) covers $45 \%$. Cattle grazing (several hundreds of heads) is observed throughout the year within grassland, and manure is spread in karstic depressions for agricultural purposes.

The Thornthwaite water budget method was used to provide an estimate of net infiltration. The results obtained indicate that all groundwater recharge during an average year occurs from October to June. The major recharge event occurs from December to April. In July, August and September, the weather is warm and evapotranspiration generally exceeds precipitation. The annual average rainfall level in the study area is $1240 \mathrm{~mm}$, and the annual average net recharge is $630 \mathrm{~mm}$ (approximately $51 \%$ of the annual average rainfall level). These values were estimated based on precipitation and temperature data recorded over an 80-year period (1921 to 2000).

\section{METHODOLOGY}

\section{Water sampling}

Spring water samples for chemical analyses were collected on a weekly basis at the perennial spring $(980$ meters above sea level [m asl], Fig. 1), from October 2006 to October 2007.

Rainwater samples for chemical analyses were collected at a rain sampler (RWS2 in Fig. 1) located within the aquifer system, at $1014 \mathrm{~m}$ asl. The sampling was carried out on a weekly basis, from October 2006 to October 2007. Ten-liter polyethylene bottles containing about $300 \mathrm{ml}$ of vaseline oil to prevent evaporation processes even under very hot summer conditions were used to collect the samples. Oil contamination was carefully avoided while syringing the water samples out of the bottle. The precipitation compositions obtained by this approach reflect wet-fall and soluble dryfall (Cryer, 1986). They are believed to more closely represent the compositions of infiltrating waters than pure wet-fall compositions (Meijer, 2002).

\section{Chemical analyses of rainwater and spring water samples}

The $\mathrm{pH}$ measurements were performed in the laboratory with a $\mathrm{pH}$ electrode and the specific conductance with a WTW laboratory conductimeter. Bicarbonate was determined by titration with $\mathrm{HCl}$. Major ions and acetate concentrations were determined by ion chromatography using a DIONEX ICS-1000 model connected to a DIONEX AS40 Automated Sampler. For cation preservation samples were filtered through a $0.45 \mu \mathrm{m}$ nylon membrane filter and acidified at $\mathrm{pH}<3$ with concentrated $\mathrm{HNO}_{3}$ solution. The accuracy of the analyses was checked by the ionic balance. As per spring water, analyses with a ionic balance of $\pm 5 \%$ were considered acceptable. Regarding rainwater, it was used the acceptable USEPA range of ion difference $(30 \%-60 \%$, for sum of ions $50-100 \mu \mathrm{eq} / 1$, and $15 \%-30 \%$ for sum of ions $>100 \mu \mathrm{eq} / 1)$. The observed difference in cations and anions always fell within this acceptable range.

\section{Chemical analyses on saturated paste extracts}

Eleven samples of Vitric Andosol were collected (six from grassland [G-type] and five from woodland [W-type]) to carry out chemical analyses on saturated paste extracts. Within grassland, three samples were collected in those areas where the soil cover is uniformly distributed $\left(\mathrm{G}_{\mathrm{u}}\right.$-type), and other three samples were taken in those areas where the soil cover is non-uniform $\left(\mathrm{G}_{\mathrm{nu}}\right.$-type) and confined into open cracks in the near-surface carbonate bedrock.

Saturated paste extracts provide information on the chemistry of solutes in soil solution because it more closely approximates the water content of the soil under field conditions.

Air dried $<2 \mathrm{~mm}$ soil samples were saturated with deionized water to create a saturated paste, the water was then extracted by centrifugation and filtered through a $0.45 \mu \mathrm{m}$ nylon membrane filter for chemical analyses. Samples (100-150 g of dried, sieved soil) were placed in beakers and deionized water was added to bring them nearly to saturation. Samples were allowed to stand overnight and then they were mixed with a spatula. At saturation, the soil paste glistens as it reflects light, flows slightly when the container is tipped, and slides freely and cleanly off the spatula except for those soils with high clay content.

Analyses included electrical conductivity (EC), alkalinity, major ions and acetate. Saturated paste extracts were analysed by the same methods as those described for spring water samples. Soil $\mathrm{pH}$ was measured on a soil water suspension (1:2.5, wt:vol).

\section{Column experiments}

A physical analogue model was developed through two column experiments to analyse the chemical evolution of water percolating through the pyroclastic soil.

Two intact soil block of Vitric Andosol (181.36 $\mathrm{cm}^{2}$ by $11 \mathrm{~cm}$ deep) were collected from the test site according to described method (Celico et al., 2004). After collection, each soil sample was covered with plastic and transported to the laboratory where the experimental procedure was commenced immediately at room temperature. A diffuse water flow was obtained carrying out the column experiment in a standard permeameter. A peristaltic pump was used to constantly push the water through the soil. Soil block drainage was entirely collected beneath the outflowing hole in several fractions to analyze changes in ions concentration over time, during each simulated event. 
During the first column test, the rainwater collected at the test site was applied on the top of the block. Two infiltration events ( $24 \mathrm{~h}$ each) were simulated in order to analyze also the effect of a period of no rainfall $(120 \mathrm{~h})$ between events. During each infiltration event, rainwater (3.0 1, corresponding to $165 \mathrm{~mm}$ of effective infiltration) was poured at a velocity of $3.5 \mathrm{~mm} / \mathrm{h}$.

During the second column test, deionized water (45.7 1) was applied on the top of the block, and poured at a velocity of $3.5 \mathrm{~mm} / \mathrm{h}$. This eleven-week long test was carried out to analyze the result of a prolonged interaction between soil medium and water. During each week, a first rainy period (48 h) was followed by a first period of no rainfall $(24 \mathrm{~h})$, and then by a second rainy period ( $24 \mathrm{~h}$ ) and a second period of no rainfall $(72 \mathrm{~h})$, in order to analyze, also in this case, the effect of a discontinuous flow through the soil column. During the tenth week no rain was simulated in order to analyze the effect of a longer period of no rainfall.

Chemical analyses of recovered samples were carried out according to the method described above.

The soil blocks for the column tests are $G_{u}$-type. From the chemical point of view, this soil type does not show significant differences if compared with that (W-type) collected in woodland (see results of chemical analyses on saturated paste extracts). Unfortunately, no blocks of the $\mathrm{G}_{\mathrm{nu}}$-type were collected for the same purpose, because this soil type is confined into open cracks in the near-surface carbonate bedrock.

\section{Microbiological investigations}

Denitrification is part of the global nitrogen cycle and allows respiration in low oxygen environments by using nitrogenous compounds as terminal electron acceptors. It is a widespread trait among prokaryotes: in fact since its discovery in 1886 by Gayon and Dupetit, a broad range of denitrifying bacteria and archaea have been described (Verbaendert et al., 2011).

The first step of the denitrification pathway is the respiratory nitrate reduction that can be performed by taxonomically diverse microorganisms including members of the $a^{-}, \beta-, \gamma^{-}$and $\varepsilon$-proteobacteria, high and low GC Gram + (Gram-positive) bacteria (Philippot, 2005).

Fecal coliforms and Pseudomonas species were isolated from twenty soil samples collected from the experimental field site, as representatives of nitratereducers and denitrifying bacteria.

Soil aliquots were initially diluted 1:1 (wt:vol) in buffered peptone-water (for fecal coliforms) and in phosphate-buffered saline (for Pseudomonas species) and resuspended by vigorous vortexing until an evenly distributed suspension was obtained. Fecal coliforms isolates were then selected by plating of 0.1-ml aliquots of appropriate 10-fold serial dilutions in buffered peptone-water (up to $10^{-5}$ ) on m-FC Agar (Biolife) for $24 \mathrm{~h}$ at $44^{\circ} \mathrm{C}$. Pseudomonas isolates were selected by plating of $0.1-\mathrm{ml}$ aliquots of appropriate 10-fold serial dilutions in phosphate-buffered saline (up to $10^{-5}$ ) on Pseudomonas selective Agar (Biolife) for $42 \mathrm{~h}$ at $37^{\circ} \mathrm{C}$.
Fecal coliforms were processed using API 20E strips (BioMerieux), following the manufacturer's instructions. API 20E is a standardized identification system for Enterobacteriaceae and other nonfastidious Gram-negative rods which uses 21 miniaturized biochemical tests and a database.

Taxonomic classification of such isolates was performed by sequence analysis of one of the 16S rRNA genes amplified with two universal oligonucleotides designed by BMR Genomics (University of Padova, Italy) to amplify $~ 500$ bp DNA fragment. Nucleotide sequencing was performed by BMR Genomics. The sequences were aligned to $16 \mathrm{~S}$ rDNA sequences obtained from the National Center for Biotechnology Information database by the Mega BLAST search (Basic Local Alignment Search Tool).

\section{Thermodynamic calculations}

Mineral saturation indexes (SI), $\mathrm{CO}_{2}$ partial pressure and the activity of dissolved species were calculated based on the complete physico-chemical analyses of the water samples. The software PHREEQCI, version 3.1.1, the Debye-Hückel equation and the thermo.com. v8.r6 thermodynamic database (as know as llnl.dat) were used for the calculations (Parkhurst \& Appelo, 1999), whereas the Act2 tool of The Geochemist's Workbench $^{\circledR}$, version 7.0.6 (GWB) with the same thermo.com.v8.r6 dataset plus other solubility data on some clay minerals from the Thermoddem database (http://thermoddem.brgm.fr; Blanc et al., 2012) were used for the construction of the mosaic activity diagrams (Bethke \& Yeakel, 2008).

\section{RESULTS AND DISCUSSION}

\section{Nitrate-reducer and denitrifying bacteria in soil}

Fecal coliforms were analyzed using colonies isolated in soil samples. These colonies were characterized with API 20E system fermentation strips showing that, out of 120 isolates, 110 were identified as Escherichia coli, 5 as Citrobacter spp., 3 as Klebsiella spp. and 2 were unidentified. Chromosomal DNA was extracted from 3 strains of each Coliform group, and PCR was performed to obtain amplification of the 16S rRNA genes. Upon BLAST comparison with the DNA GenBank, the sequences of the 16S rRNA genes revealed good agreement with the identification performed with the API system. This statement is of great importance in such a study, because $E$. coli is a nitrate-reducer bacterium (e.g., Ghiglione et al., 1999) and then it reduces nitrate to nitrite $\left[\mathrm{NO}_{3}{ }^{-} \rightarrow \mathrm{NO}_{2}^{-}\right]$. Conversely, other bacteria (denitrifying bacteria or denitrifiers) are capable of further reduction to free nitrogen $\left[\mathrm{NO}_{3}{ }^{-} \rightarrow \mathrm{NO}_{2}{ }^{-} \rightarrow \mathrm{NO} \rightarrow \mathrm{N}_{2} \mathrm{O} \rightarrow \mathrm{N}_{2}\right]$.

Denitrifying rhizobacteria belonging to the genus Pseudomonas were also detected in soil samples collected at the study site by sequence analysis. These isolates, together with those found at the same site in previous investigations (Bacillus subtilis, B. cereus, $B$. pumilus in Naclerio et al., 2009a, and Acidovorax and Flavobacterium in Petrella et al., 2009b) describe a denitrifying microbial community very similar to that found in other sites (e.g., Wang \& Skipper, 2004). 


\section{Rainwater and spring water chemistry}

The main physico-chemical features of rainwater collected at the study site were (Table 1; Fig. 2): $\mathrm{Ca}^{2+}$ and $\mathrm{HCO}_{3}^{-}$in the $48 \%$ of the events, $\mathrm{Na}^{+}$and $\mathrm{Cl}^{-}$in the $30 \%, \mathrm{Ca}^{2+}$ and $\mathrm{SO}_{4}^{2-}$ and $\mathrm{Na}^{+}$and $\mathrm{HCO}_{3}^{-}$in the $9 \%$ each, and $\mathrm{K}^{+}$and $\mathrm{HCO}_{3}{ }^{-}$in the $4 \%$. The volumeweighted mean of $\mathrm{EC}$ is $18 \mu \mathrm{S} / \mathrm{cm}$, with values ranging from $5 \mu \mathrm{S} / \mathrm{cm}$ to $83 \mu \mathrm{S} / \mathrm{cm}$ in the observation period. Considering 5.6 as the $\mathrm{pH}$ of cloud water at equilibrium with atmospheric $\mathrm{CO}_{2}$ (Charlson \& Rodhe, 1982), the $\mathrm{pH}$ of rainwater (volume-weighted mean 5.7) was in the moderately alkaline range in the $60 \%$ of the analysed samples, and in the moderately acidic range in the $40 \%$ of the samples. Taking into consideration the relative abundance of $\mathrm{Ca}^{2+}$ and $\mathrm{HCO}_{3}{ }^{-}$in rainwater, the observed alkalinity is probably due to carbonate dust particles in the atmosphere that buffers the acidity of rainwater (e.g., Kulshrestha et al., 1996; Herut et al., 2000; Kulshrestha et al., 2003). Conversely, the acid rain is due to higher concentrations of strong acids that constitute major products of atmospheric pollution of anthropogenic origin (e.g., Herut et al., 2000; de Mello, 2001; Migliavacca et al., 2005; Golobočanin et al., 2008),

Table 1. $\mathrm{pH}, \mathrm{EC}(\mu \mathrm{S} / \mathrm{cm})$ and concentrations ( $\mu \mathrm{eq} / \mathrm{l})$ of the ions analyzed in rainwater samples (Rain is the cumulated precipitation amount in $\mathrm{mm}$; $\mathrm{v}-\mathrm{w} \mathrm{m}$ is the volume-weighted mean; $\mathrm{n} . \mathrm{d}$. is not determined; dates are given in day/month/year).

\begin{tabular}{|c|c|c|c|c|c|c|c|c|c|c|c|c|c|}
\hline Date & Rain & $\begin{array}{c}\mathrm{pH} \\
\left(25^{\circ} \mathrm{C}\right) \\
\end{array}$ & $\begin{array}{c}\text { EC } \\
\left(25^{\circ} \mathrm{C}\right) \\
\end{array}$ & $\mathrm{Na}^{+}$ & $\mathrm{NH}_{4}^{+}$ & $\mathrm{K}^{+}$ & $\mathrm{Mg}^{2+}$ & $\mathrm{Ca}^{2+}$ & $\mathrm{Cl}^{-}$ & $\mathrm{NO}_{2}^{-}$ & $\mathrm{NO}_{3}^{-}$ & $\mathrm{SO}_{4}{ }^{2-}$ & $\mathrm{HCO}_{3}$ \\
\hline 02/10/06 & 92 & 5.9 & 7 & 18 & 1 & 2 & 5 & 36 & 10 & $<1$ & $<1$ & 18 & 25 \\
\hline 10/10/06 & 27 & 5.5 & 15 & 33 & 8 & 3 & 11 & 57 & 30 & $<1$ & 28 & 31 & 19 \\
\hline 08/11/06 & 17 & 6.3 & 33 & 80 & $<1$ & 89 & 19 & 78 & 89 & $<1$ & $<1$ & 34 & 123 \\
\hline $27 / 11 / 06$ & 59 & 6.3 & 8 & 28 & $<1$ & 2 & 7 & 27 & 27 & $<1$ & $<1$ & 13 & 19 \\
\hline $14 / 12 / 06$ & 50 & 6.4 & 9 & 30 & $<1$ & 2 & 9 & 24 & 30 & $<1$ & 6 & 15 & 19 \\
\hline 20/12/06 & 25 & 5.9 & 6 & 9 & $<1$ & 2 & 6 & 24 & 8 & $<1$ & 10 & 11 & 17 \\
\hline 09/01/07 & 59 & 4.7 & 22 & 49 & 11 & 4 & 13 & 21 & 52 & $<1$ & 22 & 40 & 30 \\
\hline $22 / 01 / 07$ & 34 & 4.8 & 25 & 33 & 29 & 2 & 6 & 37 & 30 & $<1$ & 43 & 47 & 38 \\
\hline 29/01/07 & 55 & 6.0 & 48 & 244 & 13 & 6 & 35 & 50 & 272 & $<1$ & 28 & 49 & 38 \\
\hline $12 / 02 / 07$ & 121 & n.d. & 9 & 20 & 8 & 1 & 7 & 14 & 19 & $<1$ & 12 & 14 & 38 \\
\hline $20 / 02 / 07$ & 109 & n.d. & 10 & 23 & 4 & 1 & 7 & 21 & 23 & $<1$ & 10 & 17 & 38 \\
\hline $26 / 02 / 07$ & 34 & 4.9 & 20 & 45 & 14 & 2 & 4 & 25 & 41 & $<1$ & 30 & 34 & 38 \\
\hline $12 / 03 / 07$ & 67 & n.d. & 12 & 20 & 10 & 1 & 4 & 24 & 19 & $<1$ & 17 & 25 & 38 \\
\hline $27 / 03 / 07$ & 124 & n.d. & 22 & 79 & 31 & 2 & 12 & 16 & 86 & $<1$ & 24 & 27 & 38 \\
\hline 02/04/07 & 8 & n.d. & 16 & 26 & 7 & 2 & 5 & 80 & 26 & $<1$ & 28 & 45 & 76 \\
\hline $10 / 04 / 07$ & 34 & n.d. & 5 & 5 & $<1$ & 1 & 2 & 24 & 4 & $<1$ & 5 & 14 & 38 \\
\hline $23 / 04 / 07$ & 25 & n.d. & 13 & 7 & 1 & 4 & 3 & 79 & 7 & $<1$ & 26 & 36 & 58 \\
\hline 07/05/07 & 64 & n.d. & 12 & 14 & $<1$ & 4 & 7 & 62 & 15 & $<1$ & $<1$ & 27 & 67 \\
\hline $11 / 06 / 07$ & 92 & n.d. & 36 & 165 & $<1$ & 8 & 33 & 65 & 184 & $<1$ & $<1$ & 46 & 48 \\
\hline $20 / 06 / 07$ & 25 & n.d. & 8 & 11 & $<1$ & 5 & 9 & 43 & 11 & $<1$ & $<1$ & 25 & 48 \\
\hline $27 / 08 / 07$ & 3 & n.d. & 83 & 144 & 49 & 41 & 25 & 369 & 174 & 4 & 79 & 108 & n.d. \\
\hline $12 / 09 / 07$ & 7 & n.d. & 71 & 121 & 63 & 24 & 21 & 293 & 127 & 3 & 99 & 125 & n.d. \\
\hline 03/10/07 & 45 & n.d. & 33 & 37 & 13 & 12 & 10 & 150 & 37 & 2 & 18 & 47 & 74 \\
\hline 08/10/07 & 35 & n.d. & 27 & 17 & 62 & 9 & 2 & 158 & 17 & $<1$ & 27 & 59 & 121 \\
\hline 29/10/07 & 20 & n.d. & 23 & 37 & 6 & 5 & 9 & 123 & 41 & $<1$ & 35 & 42 & 83 \\
\hline v-w m & & 5.7 & 18 & 52 & 10 & 5 & 11 & 46 & 54 & - & 14 & 29 & 42 \\
\hline
\end{tabular}

although natural acid inputs to the atmosphere may be important contributors (Lee \& Wakeham, 1989). Unfortunately, a not exhaustive analysis of such a topic is allowed because $\mathrm{pH}$ values were not measured from February 2007 onwards.

The main chemical feature of water samples collected at the perennial spring was of $\mathrm{Ca}^{2+}-\mathrm{HCO}_{3}$ type (Table 2; Fig. 2), with a mean $\mathrm{Mg}^{2+} / \mathrm{Ca}^{2+}=0.04 \pm$ 0.01 (mol ratio). The mean EC was $323 \mu \mathrm{S} / \mathrm{cm}$, with values ranging from $304 \mu \mathrm{S} / \mathrm{cm}$ to $339 \mu \mathrm{S} / \mathrm{cm}$ in the observation period. The $\mathrm{pH}$ of spring water was from nearly neutral to moderately alkaline.

A thorough analysis of temporal variability of physico-chemical parameters in rainwater and spring water is not necessary in this study, therefore it will be reported in a dedicated paper.

\section{Saturated paste extracts}

The results of the analyses on saturated paste extracts are summarized in Table 3. Comparing the results related to the different soil types, the following scenario can be depicted. Both $\mathrm{G}_{\mathrm{u}}$-type and $\mathrm{G}_{\mathrm{nu}}$-type are nearly neutral with $\mathrm{pH}$ values ranging from 7.0 to 7.7 (mean 7.4), and from 7.2 to 7.4 (mean 7.3), respectively. Regarding the water-soluble ions, the inorganic anion dominating the anion suite was $\mathrm{HCO}_{3}^{-}$, while the dominating cation was $\mathrm{Ca}^{2+}$ for both soil types. However, the two soil types show some differences from the chemical point of view, despite they are both related to grassland. The differences between the mean EC values, and between the mean concentrations of $\mathrm{SO}_{4}^{2-}, \mathrm{NO}_{3}^{-}$and $\mathrm{Ca}^{2+}$ are statistically significant at 0.05 level. Moreover, $\mathrm{Mg}^{2+}$ was not detected in all $\mathrm{G}_{\mathrm{nu}}$ samples. The higher concentrations of $\mathrm{NO}_{3}{ }^{-}$in $\mathrm{G}_{\mathrm{u}}$ soil are due to the more luxuriant vegetation and then to the higher organic matter content in such a soil type. In $\mathrm{G}_{\mathrm{u}}$-type soil, an organic matter content ranging from $20 \%$ to $35 \%$ was found in the test site (Naclerio et al., 2008). Moreover, the water-soluble nitrate in $G_{u}$ soil is extremely high compared to that of rainfall, while $\mathrm{NO}_{3}{ }^{-}$in $\mathrm{G}_{\mathrm{nu}}$ soil is slightly higher compared to that of precipitation (Tables 1 and 3). These findings further support that the significant alteration/transformation of soil nutrients by grassland ecosystems, within soil covers uniformly distributed in wide areas, leads to the generation of higher nitrate levels.

When comparing the grassland soils to the forest soil, no relevant differences are observed between $\mathrm{G}_{\mathrm{u}}$-type and $\mathrm{W}$-type. Conversely, the significant difference in mean concentrations of $\mathrm{NO}_{3}^{-}$between $\mathrm{G}_{\mathrm{nu}}$-type and $\mathrm{W}$-type further confirms that a more luxuriant vegetation causes an increase in nitrate in the soil medium. Thus, differently from findings in other sites (Ndala et al., 2006), forest is not the factor that governs the increase in water-soluble nitrate in the test site, but a luxuriant vegetation (both grassland and forest) uniformly distributed over a wide area.

\section{The one-week column experiment}

In Table 4 the main physico-chemical features of rainwater used to carry out the one-week column experiment are reported. 


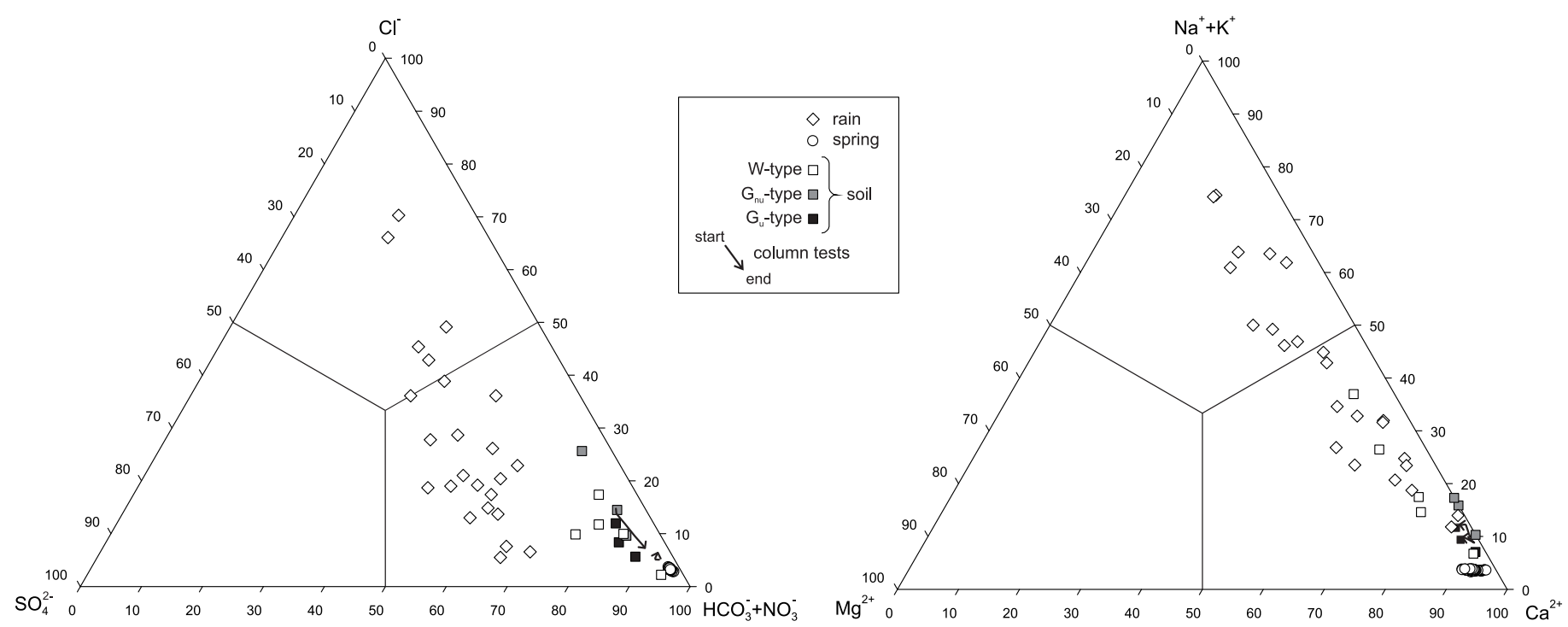

Fig. 2. Ternary diagrams for anions and cations (eq/l) of rain, soil, spring water samples and infiltration water during column tests.

\section{The first infiltration event}

When analyzing the variation of ions concentrations over time, during the first infiltration event, a great variability is observed (Fig. 3). Three main types of chemographs (time concentration curves) were observed: (a) a v-type chemograph, for $\mathrm{Ca}^{2+}, \mathrm{Mg}^{2+}$ and acetate, as well as for EC; (b) an increasing-type chemograph, for $\mathrm{HCO}_{3}{ }^{-}$and $\mathrm{Na}^{+}$, and (c) a decreasingtype chemograph, for $\mathrm{Cl}^{-}, \mathrm{SO}_{4}{ }^{2-}, \mathrm{NO}_{3}^{-}$, and $\mathrm{K}^{+}$.

Regarding the v-type chemograph, variations of $\mathrm{Ca}^{2+}$ and $\mathrm{Mg}^{2+}$ are well correlated to each other $\left(\mathrm{r}^{2}\right.$ 0.86). A lower correlation exists between $\mathrm{Ca}^{2+}$ and acetate $\left(\mathrm{r}^{2}\right.$ 0.70), while a poor correlation exists between $\mathrm{Mg}^{2+}$ and acetate $\left(\mathrm{r}^{2} 0.34\right)$.

As per the increasing-type chemograph, a good correlation is found between $\mathrm{HCO}_{3}{ }^{-}$and $\mathrm{Na}^{+}\left(\mathrm{r}^{2}\right.$ 0.91).

Regarding the decreasing-type chemograph, $\mathrm{Cl}^{-}$ and $\mathrm{SO}_{4}{ }^{2-}$ are well correlated to each other $\left(\mathrm{r}^{2} 0.87\right)$, while poor correlation was observed between the said anions and $\mathrm{K}^{+}\left(\mathrm{r}^{2} 0.40\right.$ and 0.39 , respectively). No correlation can be calculated with $\mathrm{NO}_{3}^{-}$because its concentration rapidly decreased below the limit of detection.

\section{The sequence of two infiltration events}

During the second infiltration event, all inorganic ions show a decreasing-type chemograph, with the exclusion of $\mathrm{Mg}^{2+}$ which shows a more articulated shape (Fig. 3). However, $\mathrm{Mg}^{2+}$ is characterized by a decrease in concentration during the whole infiltration process. A good correlation is found between parameters (Table 5), excluding $\mathrm{Mg}^{2+}$. This overall correlation, together with the increase in ions concentrations in the infiltration water between the end of the first event and the beginning of the second one, clearly suggest that the interaction between water and soil particles over $120 \mathrm{~h}$, at a water content near saturation, enhances mineral dissolution. Thus, from the beginning of the second event on, the fresh infiltration water causes a progressive dilution of such a water and the progressive decrease in ions concentrations in water samples collected at the soil bottom.
The synchronous variation of ions concentrations during this second infiltration event compared with the less organised behaviour of the first one seems to suggest that infiltration events close to each others enhance a more uniform response of the system.

The progressive decrease in concentration of $\mathrm{HCO}_{3}$ and $\mathrm{Ca}^{2+}$ is also well correlated with the progressive increase in acetate concentration $\left(\mathrm{r}^{2} 0.84\right.$ and 0.81 , respectively), and happened with nitrate nearly absent early during the event, and then completely absent. Such a phenomenon suggests that the simulated rainwater percolation caused anoxic conditions, and soil spontaneously formed acetate, due to the rapid response of a subcommunity of the microbiota to anearobiosis (Küsel \& Drake, 1995, 1996; Wagner et al., 1996; Küsel et al., 2002). Conversely, the absence of nitrate did not allow the oxidation of organic acids formed under anoxic conditions to $\mathrm{CO}_{2}$ (Küsel \& Drake, 1995; Wagner et al., 1996; Küsel \& Drake, 1999). Thus, the decrease in concentration of $\mathrm{HCO}_{3}^{-}$and $\mathrm{Ca}^{2+}$ seems to be also influenced by microbiological processes within the soil medium, therefore suggesting a role of the soil-specific microbial community. This phenomenon reproduces a field process, as demonstrated, at the study site, by (a) detection of acetate in fresh infiltration water (up to $76 \mathrm{meq} / 1$, Petrella et al., 2009b), and (b) existence of acetate-assimilating bacteria belonging to Betaproteobacteria and Bacteroidetes (Petrella et al., 2009b).

When analysing the sequence of the two infiltration events, differences can be observed between ions. $\mathrm{HCO}_{3}^{-}, \mathrm{Ca}^{2+}$ and $\mathrm{Mg}^{2+}$ show an increase in mean concentration (1219 to $2027 \mu \mathrm{eq} / 1,1310$ to 1733 $\mu e q / 1,18$ to $31 \mu$ eq/1, respectively), according to the increase in $\mathrm{EC}$ (170 to $218 \mu \mathrm{S} / \mathrm{cm})$. Conversely, $\mathrm{NO}_{3}{ }^{-}$, $\mathrm{NH}_{4}^{+}, \mathrm{Cl}^{-}$and acetate show a decrease in concentration (130 to $31 \mu \mathrm{eq} / 1,18$ to $8 \mu \mathrm{eq} / 1,181$ to $123 \mu \mathrm{eq} / 1,30$ to $13 \mu$ eq/1, respectively). $\mathrm{SO}_{4}{ }^{2-}, \mathrm{Na}^{+}$and $\mathrm{K}^{+}$do not show any important variations (71 to $62 \mu \mathrm{eq} / 1,164$ to 179 $\mu$ eq/1, 9 to $8 \mu$ eq/1, respectively).

The increase in mean concentration of $\mathrm{HCO}_{3}^{-}$ between infiltration events was due to an increase in 
Table 2. Temperature, $\mathrm{pH}, \mathrm{EC}(\mu \mathrm{S} / \mathrm{cm})$ and concentrations $(\mu \mathrm{eq} / \mathrm{l})$ of the ions analyzed in spring water samples (dates are given in day/month/ year). $\mathrm{CO}_{2}$ partial pressure and carbonates saturation indexes were calculated at the mean temperature of $\mathrm{T}=8.1^{\circ} \mathrm{C}$.

\begin{tabular}{|c|c|c|c|c|c|c|c|c|c|c|c|c|c|c|c|c|}
\hline Date & $\mathrm{T}\left({ }^{\circ} \mathrm{C}\right)$ & $\begin{array}{c}\mathrm{pH} \\
\left(25^{\circ} \mathrm{C}\right)\end{array}$ & $\begin{array}{c}\text { EC } \\
\left(25^{\circ} \mathrm{C}\right)\end{array}$ & $\mathrm{Na}^{+}$ & $\mathrm{NH}_{4}^{+}$ & $\mathrm{K}^{+}$ & $\mathrm{Mg}^{2+}$ & $\mathrm{Ca}^{2+}$ & $\mathrm{Cl}^{-}$ & $\mathrm{NO}_{2}^{-}$ & $\mathrm{NO}_{3}^{-}$ & $\mathrm{SO}_{4}^{2-}$ & $\mathrm{HCO}_{3}^{-}$ & $\log \mathrm{P}\left(\mathrm{CO}_{2}\right)$ & $\mathrm{SI}_{\text {calcite }}$ & $\mathrm{SI}_{\text {dolomite-ord. }}$ \\
\hline $02 / 10 / 06$ & 8.8 & 7.6 & 322 & 101 & $<1$ & 14 & 153 & 3268 & 108 & 9 & 17 & 55 & 3127 & -2.56 & 0.18 & 0.13 \\
\hline $10 / 10 / 06$ & 8.7 & 7.5 & 311 & 104 & $<1$ & 14 & 148 & 3037 & 111 & 9 & 15 & 56 & 3023 & -2.47 & 0.03 & -0.15 \\
\hline $16 / 10 / 06$ & 8.3 & 7.6 & 309 & 105 & $<1$ & 14 & 149 & 3035 & 112 & 10 & 15 & 56 & 3004 & -2.59 & 0.13 & 0.06 \\
\hline $24 / 10 / 06$ & 8.4 & 7.6 & 308 & 97 & $<1$ & 13 & 146 & 2814 & 108 & 10 & 15 & 53 & 2985 & -2.59 & 0.10 & 0.02 \\
\hline $30 / 10 / 06$ & 8.3 & 7.7 & 307 & 99 & $<1$ & 14 & 149 & 2860 & 109 & 9 & 14 & 54 & 2976 & -2.70 & 0.21 & 0.25 \\
\hline $16 / 11 / 06$ & 8.0 & 7.7 & 308 & 103 & $<1$ & 14 & 161 & 2935 & 112 & 8 & 16 & 54 & 2985 & -2.70 & 0.22 & 0.28 \\
\hline $22 / 11 / 06$ & 7.7 & 7.7 & 306 & 103 & $<1$ & 15 & 163 & 2985 & 117 & 10 & 16 & 55 & 2976 & -2.71 & 0.23 & 0.29 \\
\hline $27 / 11 / 06$ & 7.5 & 7.7 & 304 & 107 & $<1$ & 15 & 159 & 2994 & 113 & 9 & 15 & 52 & 2994 & -2.71 & 0.23 & 0.28 \\
\hline $04 / 12 / 06$ & 7.3 & 8.0 & 308 & 106 & $<1$ & 16 & 176 & 2902 & 109 & 8 & 15 & 50 & 3042 & -3.06 & 0.56 & 0.99 \\
\hline $14 / 12 / 06$ & 6.9 & 7.9 & 305 & 107 & $<1$ & 16 & 159 & 2942 & 111 & 9 & 16 & 51 & 3061 & -2.95 & 0.45 & 0.73 \\
\hline $20 / 12 / 06$ & 6.8 & 8.1 & 315 & 106 & $<1$ & 16 & 184 & 3008 & 111 & 12 & 16 & 50 & 3117 & -3.19 & 0.70 & 1.28 \\
\hline 29/12/06 & 6.7 & 7.7 & 314 & 106 & $<1$ & 17 & 164 & 3083 & 111 & 11 & 18 & 52 & 3174 & -2.70 & 0.26 & 0.34 \\
\hline 03/01/07 & 7.0 & 7.9 & 316 & 106 & $<1$ & 17 & 160 & 3099 & 109 & 11 & 15 & 52 & 3174 & -2.93 & 0.49 & 0.79 \\
\hline 09/01/07 & 7.2 & 7.9 & 331 & 106 & $<1$ & 16 & 145 & 3296 & 105 & 10 & 17 & 54 & 3363 & -2.91 & 0.54 & 0.81 \\
\hline $16 / 01 / 07$ & 6.7 & 7.5 & 336 & 105 & $<1$ & 16 & 117 & 3262 & 103 & 11 & 15 & 54 & 3344 & -2.46 & 0.09 & -0.18 \\
\hline $22 / 01 / 07$ & 7.5 & 7.8 & 339 & 105 & $<1$ & 15 & 141 & 3292 & 99 & 11 & 14 & 51 & 3401 & -2.78 & 0.43 & 0.59 \\
\hline $29 / 01 / 07$ & 7.1 & 7.8 & 338 & 107 & $<1$ & 15 & 123 & 3323 & 102 & 11 & 14 & 54 & 3363 & -2.79 & 0.43 & 0.52 \\
\hline $06 / 02 / 07$ & 6.9 & 7.9 & 337 & 107 & $<1$ & 15 & 98 & 3305 & 106 & 11 & 13 & 56 & 3344 & -2.92 & 0.54 & 0.64 \\
\hline $12 / 02 / 07$ & 7.6 & 7.7 & 337 & 107 & $<1$ & 13 & 130 & 3310 & 99 & 11 & 15 & 44 & 3363 & -2.67 & 0.32 & 0.32 \\
\hline $20 / 02 / 07$ & 7.9 & 7.5 & 338 & 114 & $<1$ & 13 & 94 & 3413 & 109 & 14 & 12 & 52 & 3438 & -2.43 & 0.13 & -0.21 \\
\hline $26 / 02 / 07$ & 8.1 & 7.8 & 335 & 114 & $<1$ & 13 & 88 & 3393 & 105 & 9 & 10 & 51 & 3382 & -2.77 & 0.44 & 0.40 \\
\hline 05/03/07 & 8.1 & 7.6 & 328 & 111 & $<1$ & 13 & 90 & 3339 & 107 & 13 & 10 & 55 & 3344 & -2.55 & 0.22 & -0.04 \\
\hline $12 / 03 / 07$ & 7.7 & 7.4 & 333 & 109 & $<1$ & 13 & 86 & 3357 & 111 & 13 & 12 & 58 & 3363 & -2.34 & 0.01 & -0.48 \\
\hline $02 / 04 / 07$ & 7.9 & 7.6 & 333 & 111 & $<1$ & 13 & 81 & 3298 & 108 & 11 & 11 & 55 & 3438 & -2.54 & 0.22 & -0.08 \\
\hline $10 / 04 / 07$ & 8.0 & 7.6 & 334 & 116 & $<1$ & 14 & 98 & 3376 & 101 & 8 & 10 & 51 & 3348 & -2.55 & 0.22 & -0.01 \\
\hline $23 / 04 / 07$ & 8.7 & 7.2 & 333 & 113 & $<1$ & 14 & 72 & 3311 & 107 & 9 & 10 & 55 & 3329 & -2.12 & -0.20 & -0.97 \\
\hline $30 / 04 / 07$ & 8.7 & 7.7 & 333 & 111 & $<1$ & 14 & 62 & 3202 & 109 & 12 & 10 & 54 & 3310 & -2.65 & 0.31 & 0.00 \\
\hline $07 / 05 / 07$ & 9.2 & 7.5 & 332 & 111 & $<1$ & 13 & 100 & 3244 & 108 & 12 & 14 & 54 & 3329 & -2.42 & 0.10 & -0.20 \\
\hline $14 / 05 / 07$ & 9.0 & 7.6 & 336 & 110 & $<1$ & 14 & 65 & 3241 & 105 & 12 & 11 & 58 & 3310 & -2.54 & 0.21 & -0.18 \\
\hline $21 / 05 / 07$ & 9.4 & 7.7 & 331 & 112 & $<1$ & 13 & 57 & 3289 & 107 & 13 & 12 & 60 & 3310 & -2.64 & 0.32 & -0.01 \\
\hline $28 / 05 / 07$ & 9.4 & 7.5 & 331 & 112 & $<1$ & 13 & 106 & 3295 & 105 & 10 & 12 & 56 & 3290 & -2.43 & 0.10 & -0.18 \\
\hline $04 / 06 / 07$ & 8.7 & 7.6 & 327 & 110 & $<1$ & 14 & 115 & 3247 & 107 & 11 & 12 & 59 & 3271 & -2.55 & 0.20 & 0.05 \\
\hline $11 / 06 / 07$ & 9.3 & 7.6 & 327 & 112 & $<1$ & 14 & 116 & 3250 & 106 & 12 & 12 & 59 & 3252 & -2.54 & 0.20 & 0.06 \\
\hline $20 / 06 / 07$ & 9.6 & 7.6 & 326 & 111 & $<1$ & 14 & 117 & 3205 & 107 & 13 & 12 & 56 & 3252 & -2.54 & 0.20 & 0.07 \\
\hline 03/07/07 & 9.7 & 7.6 & 327 & 110 & $<1$ & 14 & 140 & 3179 & 110 & 12 & 12 & 57 & 3233 & -2.54 & 0.19 & 0.14 \\
\hline 09/07/07 & 9.4 & 7.2 & 328 & 110 & $<1$ & 14 & 127 & 3167 & 109 & 13 & 12 & 56 & 3252 & -2.12 & -0.22 & -0.74 \\
\hline $16 / 07 / 07$ & 9.8 & 7.7 & 325 & 111 & $<1$ & 14 & 137 & 3167 & 109 & 12 & 12 & 59 & 3252 & -2.64 & 0.30 & 0.35 \\
\hline $23 / 07 / 07$ & 9.7 & 7.3 & 323 & 110 & $<1$ & 14 & 137 & 3132 & 108 & 12 & 12 & 56 & 3213 & -2.22 & -0.13 & -0.51 \\
\hline $30 / 07 / 07$ & 9.9 & 7.3 & 322 & 110 & $<1$ & 14 & 141 & 3122 & 108 & 11 & 11 & 55 & 3213 & -2.22 & -0.13 & -0.49 \\
\hline 06/08/07 & 9.6 & 7.3 & 319 & 110 & $<1$ & 14 & 117 & 3112 & 107 & 13 & 12 & 58 & 3179 & -2.23 & -0.13 & -0.59 \\
\hline $27 / 08 / 07$ & 9.7 & 7.5 & 324 & 111 & $<1$ & 14 & 115 & 3089 & 109 & 12 & 12 & 58 & 3161 & -2.44 & 0.07 & -0.19 \\
\hline 03/09/07 & 8.3 & 7.2 & 319 & 110 & $<1$ & 14 & 123 & 3074 & 110 & 15 & 13 & 58 & 3161 & -2.15 & -0.25 & -0.81 \\
\hline $12 / 09 / 07$ & 8.8 & 7.0 & 317 & 111 & $<1$ & 14 & 120 & 3072 & 110 & 13 & 12 & 55 & 3123 & -1.94 & -0.46 & -1.22 \\
\hline $17 / 09 / 07$ & 8.7 & 7.1 & 315 & 110 & $<1$ & 14 & 118 & 3041 & 111 & 13 & 12 & 56 & 3123 & -2.04 & -0.36 & -1.03 \\
\hline $24 / 09 / 07$ & 8.9 & 7.6 & 315 & 111 & $<1$ & 15 & 134 & 3031 & 110 & 13 & 11 & 55 & 3123 & -2.57 & 0.16 & 0.06 \\
\hline 03/10/07 & 8.8 & 7.6 & 314 & 111 & $<1$ & 15 & 144 & 3032 & 111 & 13 & 12 & 56 & 3061 & -2.58 & 0.15 & 0.07 \\
\hline 08/10/07 & 8.8 & 7.6 & 313 & 111 & $<1$ & 15 & 125 & 3021 & 113 & 15 & 12 & 55 & 3080 & -2.58 & 0.15 & 0.02 \\
\hline
\end{tabular}


Table 3. $\mathrm{pH}, \mathrm{EC}(\mu \mathrm{S} / \mathrm{cm})$ and concentrations $(\mu \mathrm{eq} / \mathrm{l})$ of the ions analyzed in saturated paste extracts obtained from soil samples $\mathrm{G}_{u}-1$ to $\mathrm{G}_{\mathrm{u}}-3, \mathrm{G}_{\mathrm{nu}}{ }^{-}$ 1 to $\mathrm{G}_{\mathrm{nu}}-3$ and $\mathrm{W}-1$ to $\mathrm{W}-5$. At the bottom, the values of $\mathrm{pH}, \mathrm{CO}_{2}$ partial pressure and saturation indexes of carbonates calculated at the mean temperature of the local spring waters $\left(T=8.1^{\circ} \mathrm{C}\right)$ are shown for comparison.

\begin{tabular}{|c|c|c|c|c|c|c|c|c|c|c|c|c|c|c|}
\hline \multirow{2}{*}{ Parameter } & \multicolumn{4}{|c|}{ Grassland soil (G-type) } & \multicolumn{5}{|c|}{ Grassland soil (Gnu-type) } & \multicolumn{5}{|c|}{ Woodland soil (W-type) } \\
\hline & $\mathrm{G}_{\mathrm{u}}-1$ & $\mathrm{G}_{u}-2$ & $\mathrm{G}_{\mathrm{u}}-3$ & Mean & $\mathrm{G}_{\mathrm{nu}}-1$ & $\mathrm{G}_{\mathrm{nu}}-2$ & $\mathrm{G}_{\mathrm{nu}}-3$ & Mean & $W-1$ & W-2 & W-3 & W-4 & W-5 & Mean \\
\hline $\mathrm{pH}\left(25^{\circ} \mathrm{C}\right)$ & 7.0 & 7.4 & 7.7 & 7.4 & 7.2 & 7.4 & 7.2 & 7.3 & 5.9 & 6.0 & 6.3 & 7.7 & 6.2 & 6.4 \\
\hline $\mathrm{EC}\left(25^{\circ} \mathrm{C}\right)$ & 578 & 429 & 585 & 531 & 149 & 337 & 172 & 219 & 311 & 328 & 545 & 401 & 588 & 435 \\
\hline $\mathrm{Na}^{+}$ & 287 & 353 & 306 & 315 & 220 & 284 & 249 & 251 & 609 & 516 & 388 & 200 & 464 & 435 \\
\hline $\mathrm{NH}_{4}^{+}$ & 139 & 12 & 13 & 55 & $<1$ & 13 & $<1$ & - & 75 & 56 & 784 & 53 & 555 & 305 \\
\hline $\mathrm{K}^{+}$ & 160 & 50 & 39 & 83 & 12 & 31 & 26 & 23 & 235 & 110 & 315 & 68 & 158 & 177 \\
\hline $\mathrm{Mg}^{2+}$ & 140 & 89 & 81 & 103 & $<1$ & $<1$ & $<1$ & - & 153 & 183 & 232 & 72 & 291 & 186 \\
\hline $\mathrm{Ca}^{2+}$ & 4178 & 2972 & 4449 & 3866 & 1229 & 2738 & 1313 & 1760 & 1287 & 1557 & 3086 & 3505 & 3346 & 2556 \\
\hline $\mathrm{Cl}^{-}$ & 247 & 356 & 370 & 324 & 111 & 711 & 191 & 338 & 231 & 424 & 379 & 71 & 524 & 326 \\
\hline $\mathrm{NO}_{2}$ & 58 & 342 & 283 & 228 & 17 & 66 & 17 & 33 & 37 & 33 & 204 & 216 & 124 & 123 \\
\hline $\mathrm{NO}_{3}{ }^{-}$ & 2693 & 1277 & 2335 & 2102 & 281 & 255 & 322 & 286 & 1393 & 1305 & 1611 & 944 & 2589 & 1568 \\
\hline $\mathrm{SO}_{4}^{2-}$ & 269 & 185 & 332 & 262 & 65 & 136 & 62 & 88 & 138 & 153 & 533 & 117 & 406 & 269 \\
\hline $\mathrm{HCO}_{3}^{-}$ & 1160 & 1160 & 1391 & 1237 & 696 & 1670 & 742 & 1036 & 557 & 557 & 1321 & 2076 & 944 & 1091 \\
\hline $\mathrm{pH}\left(8.1^{\circ} \mathrm{C}\right)$ & 7.06 & 8.66 & 8.71 & 8.14 & 7.36 & 7.60 & 7.36 & 7.44 & 6.00 & 6.11 & 6.27 & 8.23 & 6.18 & 6.56 \\
\hline $\log \mathrm{P}\left(\mathrm{CO}_{2}\right)$ & -2.33 & -3.90 & -3.90 & -3.38 & -2.82 & -2.69 & -2.79 & -2.77 & -1.58 & -1.68 & -1.56 & -3.23 & -1.61 & -1.93 \\
\hline $\mathrm{SI}_{\text {Calcite }}$ & -0.86 & 0.63 & 0.88 & 0.22 & -1.22 & -0.29 & -1.16 & -0.89 & -2.68 & -2.50 & -1.78 & 0.51 & -1.99 & -1.69 \\
\hline$S I_{\text {Dolomite-Ord }}$ & -2.10 & 0.84 & 1.13 & -0.04 & -4.72 & -3.23 & -4.65 & -4.20 & -5.20 & -4.82 & -3.59 & 0.44 & -3.95 & -3.42 \\
\hline
\end{tabular}

$\mathrm{CO}_{2}$ production in the soil column from the end of the first event and the beginning of the second one, that enhanced carbonate dissolution, as revealed by the switch of the mean $\log \left(\mathrm{CO}_{2}\right)$ from -2.89 to -2.84 and the obtainment of the equilibrium with calcite, respectively (Fig. 3). During such a period, the soil column was open to the atmosphere and soil respiration probably increased due to better aerated conditions within the column. This is in agreement with several studies that demonstrated that the optimum for soil respiration is frequently found at intermediate water contents (Orchard \& Cook, 1983; Howard \& Howard, 1993; Davidson et al., 2000). Furthermore, according to Linn \& Doran (1984), microbial respiration is limited in very wet soils due to limitation of $\mathrm{O}_{2}$ diffusion through pores (oxygen is needed for aerobic respiration), and in very dry soils due to limitation of soluble organic-C substrates in water films (soluble organic substrates are used as energy sources by heterotrophic microorganisms). Thus, the optimum water content is generally somewhere near field capacity, where the macropore spaces are mostly air-filled (facilitating $\mathrm{O}_{2}$ diffusion), and the micropore spaces are mostly water-filled (facilitating diffusion of soluble substrates).

The decrease in mean concentration of $\mathrm{NO}_{3}^{-}$from the first to the second infiltration event (130 to $31 \mu \mathrm{eq} / 1)$ may be due to denitrification and nitrate reduction. Also in this case, some of the bacteria isolated at

Table 4. $\mathrm{pH}, \mathrm{EC}(\mu \mathrm{S} / \mathrm{cm})$ and concentrations $(\mu \mathrm{eq} / \mathrm{l})$ of the ions analyzed in rainwater used for the one-week column experiment.

\begin{tabular}{cccccccccccc}
\hline $\begin{array}{c}\mathrm{pH} \\
\text { (at 25ㅇ) }\end{array}$ & $\begin{array}{c}\mathrm{EC} \\
\left.\text { (at } 25^{\circ} \mathrm{C}\right)\end{array}$ & $\mathrm{Na}^{+}$ & $\mathrm{NH}_{4}^{+}$ & $\mathrm{K}^{+}$ & $\mathrm{Mg}^{2+}$ & $\mathrm{Ca}^{2+}$ & $\mathrm{Cl}^{-}$ & $\mathrm{NO}_{2}^{-}$ & $\mathrm{NO}_{3}^{-}$ & $\mathrm{SO}_{4}^{2-}$ & $\mathrm{HCO}_{3}^{-}$ \\
\hline 6.0 & 18 & 64 & 13 & 2 & 7 & 51 & 60 & $<1$ & 18 & 19 & 66 \\
\hline
\end{tabular}

the Acqua dei Faggi experimental site belong to genera and species that are classified as denitrifying rhizobacteria (Bacillus subtilis, B. cereus, B. pumilus, Acidovorax sp., Flavobacterium sp., Pseudomonas sp.) or nitrate-reducers (E. coli).

Taking into consideration the existence of anoxic conditions during the infiltration events, as shown by acetate formation, the decrease in mean concentrations of $\mathrm{NH}_{4}{ }^{+}$in the same water samples ( 18 to $8 \mu \mathrm{eq} / 1$ ) should be due to anaerobic ammonium oxidation (anammox) processes that allow $\mathrm{NH}_{4}{ }^{+}$to be oxidized under anoxic conditions (Strous et al., 1999). Anammox is performed by autotrophic bacteria that were detected in relatively few, mostly marine environments (e.g., Kuypers et al., 2003), even though they were recently detected also in freshwater sediments (e.g., Penton et al., 2006). However, no information exists to date on the presence of such bacteria in the studied soil. Microbiological investigations are in progress to verify the effectiveness of this hypothesis.

The relatively high concentration of $\mathrm{NO}_{2}^{-}$in soil infiltration water may be the product of nitrate reduction performed by $E$. coli and other nitratereducers bacteria. We hypothesize that such a production is higher than biological conversion of nitrite to dinitrogen gas during anammox processes.

\section{The eleven-week column experiment}

During the eleven-week long test, all the analyzed ions describe similar breakthrough curves, even though the peak concentrations do not perfectly correspond (see examples in Fig. 4). This phenomenon suggests that the analyzed soil medium is a set of different sources of chemical species that interact differently with water during its percolation. The long 

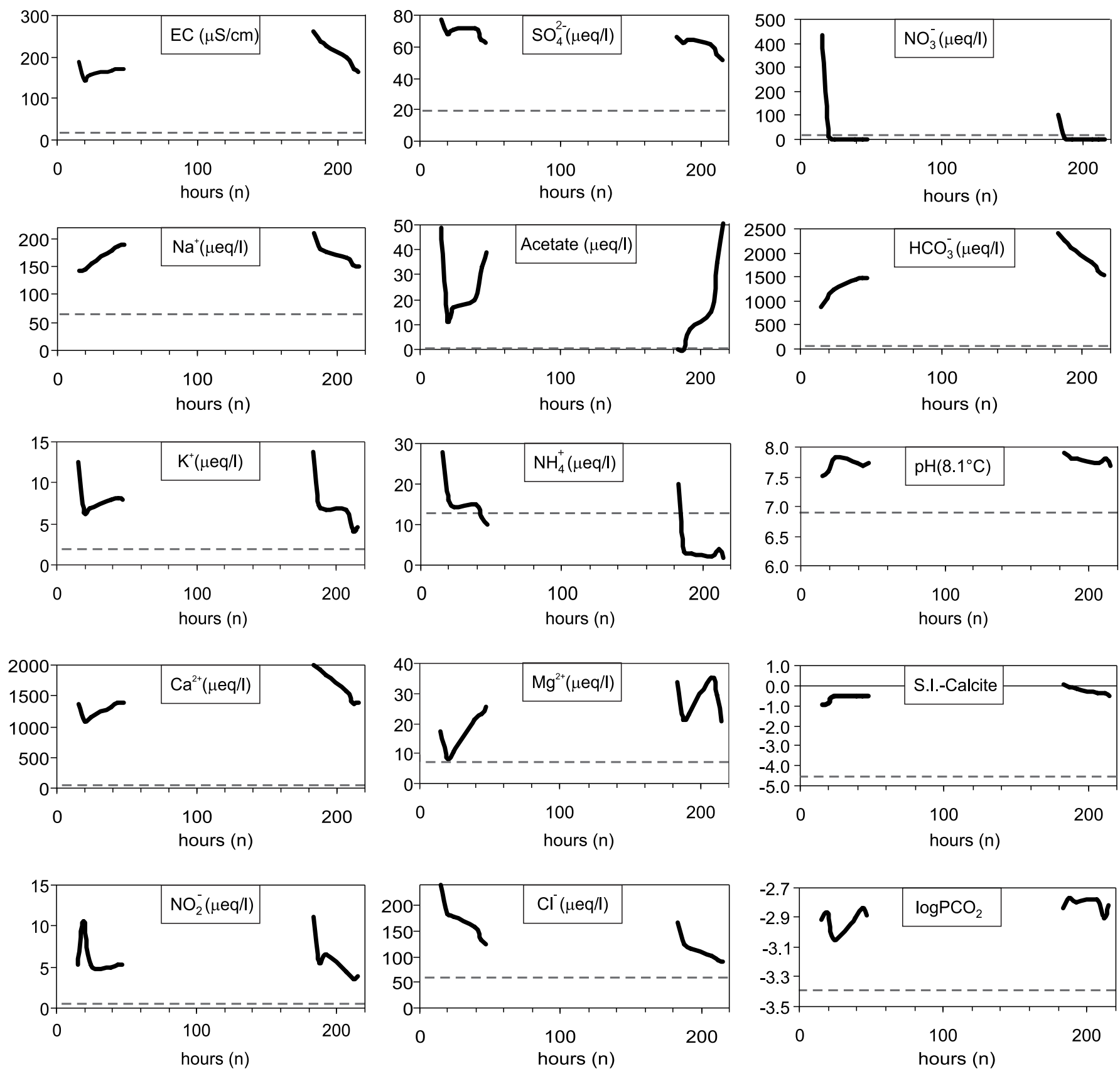

Fig. 3. Results of the one-week column experiment. The gray dashed line represents the composition of the rainwater used for the experiment. $\mathrm{pH}$, $\log \mathrm{PCO}_{2}$ and the calcite saturation index were recalculated at the mean temperature of the springs $\left(\mathrm{T}=8.1^{\circ} \mathrm{C}\right)$.

tailing and the generalized decrease in concentration of all ions after several weeks suggest that one or more of these sources are exhaustible in the physical analogue model, which is isolated with respect to other environmental components. In particular, $\mathrm{Ca}^{2+}$ and $\mathrm{Mg}^{2+}$ showed similar paths, with a downwarding

Table 5. Correlation coefficients between ionic concentrations in infiltration water collected during the second infiltration event (oneweek column experiment).

\begin{tabular}{|c|c|c|c|c|c|c|}
\hline & $\mathrm{Na}^{+}$ & $\mathrm{K}^{+}$ & $\mathrm{Mg}^{2+}$ & $\mathrm{Ca}^{2+}$ & $\mathrm{Cl}^{-}$ & $\mathrm{SO}_{4}{ }^{2-}$ \\
\hline $\mathrm{K}^{+}$ & 0.92 & & & & & \\
\hline $\mathrm{Mg}^{2+}$ & 0.09 & 0.20 & & & & \\
\hline $\mathrm{Ca}^{2+}$ & 0.86 & 0.64 & 0.01 & & & \\
\hline $\mathrm{Cl}^{-}$ & 0.98 & 0.94 & 0.09 & 0.80 & & \\
\hline $\mathrm{SO}_{4}^{2-}$ & 0.75 & 0.58 & 0.14 & 0.84 & 0.64 & \\
\hline $\mathrm{HCO}_{3}$ & 0.90 & 0.68 & 0.01 & 0.99 & 0.84 & 0.82 \\
\hline
\end{tabular}

$\mathrm{Mg}^{2+} / \mathrm{Ca}^{2+}$ ratio towards the mean spring water value (0.04), testifying the buffering effect of (microcrystalline) carbonate minerals also in the soil (Fig. 4). Also $\mathrm{Na}^{+}$and $\mathrm{Cl}^{-}$paths are similar, however their ratio was inverted after $250 \mathrm{~h}$ because to the more rapid decrease of $\mathrm{Cl}^{-}$concentration. This effect, coupled with the disappearing of $\mathrm{SO}_{4}{ }^{2-}$ after $216 \mathrm{~h}$, is in agreement with the anions adsorption in Andisols demonstrated by other authors (Katou, 2004; Pigna et al., 2007). The different breakthroughs of $\mathrm{K}^{+}$and $\mathrm{NH}_{4}^{+}$with respect to those described by the other ions, suggest that $\mathrm{K}^{+}$and $\mathrm{NH}_{4}^{+}$are dissolved, totally or in part, from a different source.

Other to small crystals of residual K-bearing primary silicates as muscovite, biotite and K-feldspars, should be taking into consideration that $\mathrm{G}_{\mathrm{u}}$-type soil is characterized by luxuriant vegetation and high organic matter, therefore another probable exhaustible 


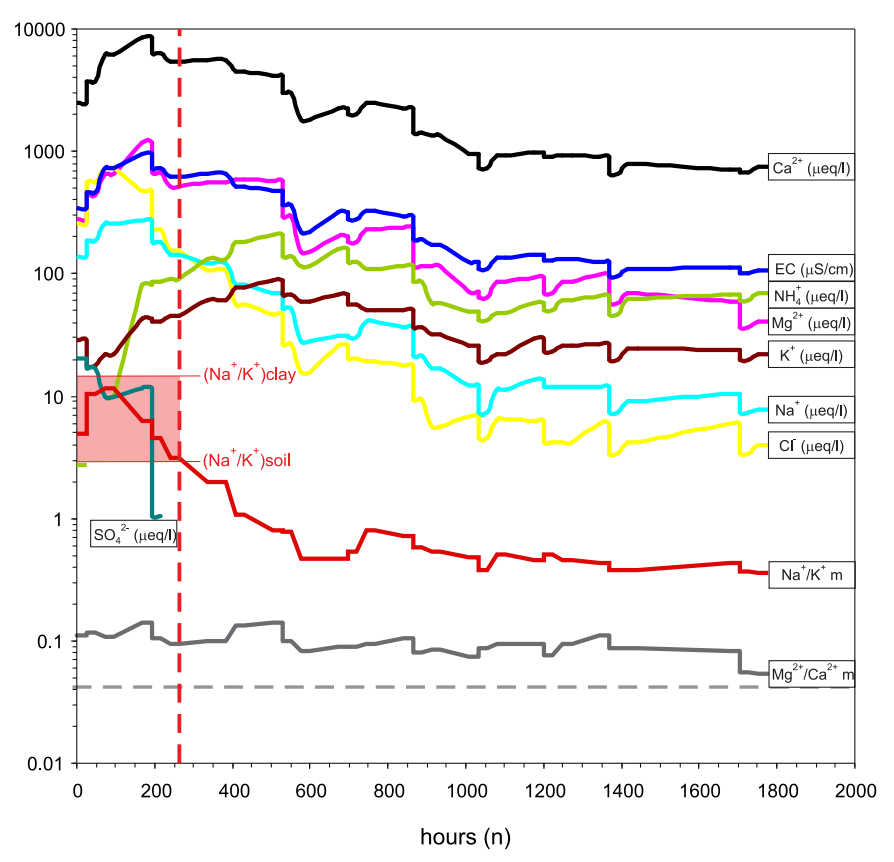

Fig. 4. Ions ( $\mu \mathrm{eq} / \mathrm{l}), \mathrm{EC}(\mu \mathrm{S} / \mathrm{cm})$ and molar ratios $(\mathrm{m})$ behaviour observed during the eleven-week column experiment. $\mathrm{K}^{+}$ concentrations did not increase shortly after the onset of the experiment and it showed a long tailing; $\mathrm{NH}_{4}{ }^{+}$behaved like $\mathrm{K}^{+}$. Chemograph shapes were similar for $\mathrm{Ca}^{2+}, \mathrm{Mg}^{2+}$ and $\mathrm{EC}$ and for $\mathrm{Na}^{+}$ and $\mathrm{Cl}^{-} \mathrm{SO}_{4}{ }_{4}^{2-}$ showed the maximum concentration at the onset of the experiment, afterwards its concentration rapidly decrease below the limit of detection. Pink square represents the $\mathrm{Na}^{+} / \mathrm{K}^{+}$buffering by local soil $\left(\mathrm{Na}^{+} / \mathrm{K}^{+}=2.9 \mathrm{~m}\right)$ and theoretical composition of clay minerals $\left(\mathrm{Na}^{+} / \mathrm{K}^{+}=10.6 \mathrm{~m}\right)$, this latter ratio calculated by GWB software imposing simultaneous equilibrium between a couple of various $\mathrm{Na}$ and K-clay minerals (e.g. montmorillonite, nontronite, saponite). The vertical and red dashed line intercepts the curves at $h=250$, which corresponded to different but simultaneous events $(\mathrm{Na} / \mathrm{Cl}$ switch, $\mathrm{SO}_{4}{ }^{2-}$ disappear, $\mathrm{K}^{+}$control by other sources but soil clays).

source of potassium in the analogue model are plant cells. Potassium is an essential macronutrient, which is important for various aspects of plant life and, in contrast to other metals, the concentration of $\mathrm{K}^{+}$in plant cells is very high (up to $8 \%$ of the dry weight; Evans \& Sorger, 1966). At the same time, $\mathrm{NH}_{4}^{+}$should be due to ammonia dissolution in water, where ammonia is produced naturally from decomposition of organic matter. Another exhaustible source can be salts precipitated during the hotter periods of a hydrologic year, due to evaporation of rainwater in the soil. This hypothesis is supported by data shown hereafter. In any case, the $\mathrm{Na}^{+} / \mathrm{K}^{+}$ratio appeared to be mainly controlled by soil clay minerals at $\mathrm{h}<250$, whereas the supply of $\mathrm{K}^{+}$from additional sources drove the decline of the ratio at $h>250$ (Fig. 4).

\section{Relationships between rainwater, soil infiltration water and spring water chemistry}

When comparing the spring water chemistry to the results of the one-week column experiment, that was carried out using rainwater, a great influence of pyroclastic soil on the physico-chemical signature of spring water was observed. After percolating through the 11-cm-thick soil column, infiltration water had its chemistry significantly modified with respect to rainwater.

Mean concentrations of $\mathrm{Cl}^{-}$and $\mathrm{SO}_{4}{ }^{2-}$ increased (two to three-fold greater in soil infiltration water than in rainwater) and their values were in the range of those characteristic of spring water (Fig. 5). However, the $\mathrm{SO}_{4}^{2-} / \mathrm{Cl}^{-}$ratio (eq. ratio) in this infiltration water ( 0.39 to 0.50 ) is very close to the ratio in spring water (0.51) and to the ratio in rainwater $(0.32$ in the sample used during the column test, and 0.54, in average, in rainwater collected at the study site throughout this work). Thus, the concentration of these anions in spring water seems to be governed by interaction between infiltration water and soil medium, but its ratio is the same detected in rainwater.

Mean concentrations of $\mathrm{Na}^{+}$also increased (more than two-fold greater in soil infiltration water than in rainwater), but the values in soil infiltration water (164 and $179 \mu \mathrm{eq} / 1$ during the first and the second infiltration events, respectively) are higher than that (109 $\mu \mathrm{eq} / \mathrm{l})$ observed in spring water (Fig. 5).

The higher mean concentration of $\mathrm{K}^{+}$in spring water than in soil infiltration water (Fig. 5), together with the lower mean concentration of $\mathrm{Na}^{+}$, may be due to cation exchange $\left(\mathrm{Na}^{+}\right.$for $\mathrm{K}^{+}$; e.g., Scott \& Smith, 1966) between water and clay minerals in marls interbedded in the limestone sequence within the carbonate aquifer. This phenomenon is further emphasised by the $\mathrm{K}^{+} / \mathrm{Na}^{+}$ratio that increases from 0.05-0.06 in soil infiltration water to 0.13 in spring water. In this
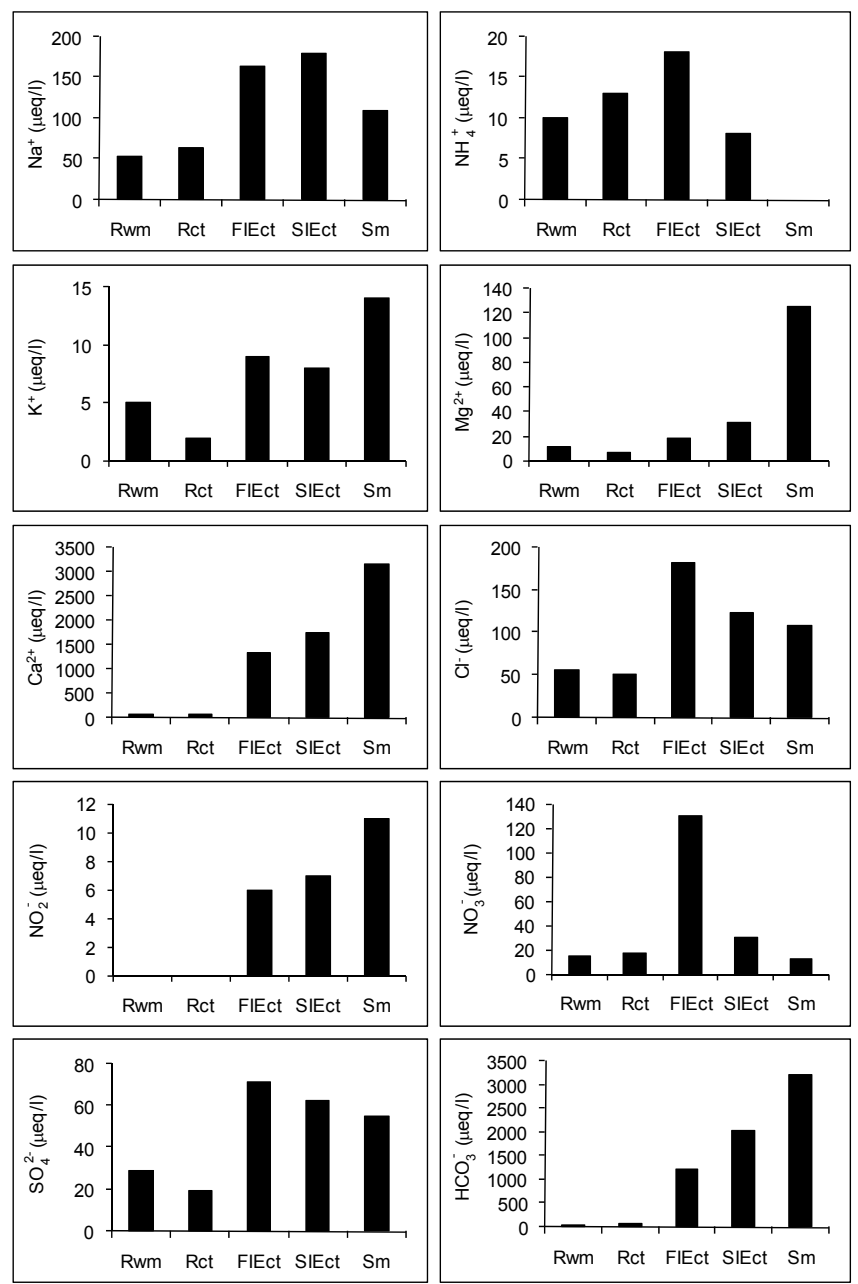

Fig. 5. Water chemistry evolution from rainwater to spring water (Rwm is the weighted mean concentration in rainwater; Rct is the concentration in rainwater used for the one-week column test; FIEct is the mean concentration in soil infiltration water during the first infiltration event simulated during the one-week column test; SIEct is the mean concentration in soil infiltration water during the second infiltration event simulated during the one-week column test; $\mathrm{Sm}$ is the mean concentration in spring water). 
study, was not possible to calculate the saturation indexes between waters and silicates due to the lacks of dissolved silica and aluminium concentrations. However, it's well known that waters are promptly saturated in a $\mathrm{Al}_{2} \mathrm{Si}_{2} \mathrm{O}_{5}(\mathrm{OH})_{4}$ phase, e.g., kaolinite, at very low silica concentration, in particular where primary silicates are present in the cover strata as in this case (e.g., Boschetti \& Toscani, 2008). Therefore, supposing that $\mathrm{Al}$ and $\mathrm{SiO}_{2}(\mathrm{aq})$ were buffered by kaolinite, the $\left[\mathrm{K}^{+}\right] /\left[\mathrm{H}^{+}\right]$and $\left[\mathrm{Na}^{+}\right] /\left[\mathrm{H}^{+}\right]$activity ratios obtained from thermodynamic speciation on water samples at the mean temperature of $8.1^{\circ} \mathrm{C}$ can be combined with the solubility data of the minerals to obtain a mosaic diagram (Fig. 6). As showed by the straight path of the samples, the primary phases muscovite, $\mathrm{K}$-feldspar and albite may furnish $\mathrm{K}^{+}$and $\mathrm{Na}^{+}$to the infiltrating waters, whereas clay minerals as illite or nontronite buffered their concentration. Results did not appreciably changed if saturation was imposed for poorly crystalline $\mathrm{Al}_{2} \mathrm{Si}_{2} \mathrm{O}_{5}(\mathrm{OH})_{4}$ as imogolite or halloysite, more typical of Andisols.

The higher concentrations of $\mathrm{HCO}_{3}^{-}, \mathrm{Ca}^{2+}$ and $\mathrm{Mg}^{2+}$ in spring water are due to a significant carbonate dissolution occurred mainly in the carbonate aquifer. In fact, when all water samples are plotted in comparison with the $\mathrm{Ca}^{2+} / \mathrm{HCO}_{3}^{-}$equivalent ratios of 1.0 and 0.5 obtainable from the dissolution reactions of calcite

$$
\mathrm{CaCO}_{3}+\mathrm{CO}_{2}+\mathrm{H}_{2} \mathrm{O} \rightarrow \mathrm{Ca}^{2+}+2 \mathrm{HCO}_{3}^{-}
$$

and dolomite

$$
\mathrm{CaMg}\left(\mathrm{CO}_{3}\right)_{2}+2 \mathrm{CO}_{2}+2 \mathrm{H}_{2} \mathrm{O} \rightarrow \mathrm{Ca}^{2+}+\mathrm{Mg}^{2+}+4 \mathrm{HCO}_{3}^{-}
$$

respectively, the spring waters are clustered near to the calcite dissolution line (Fig. 7), testifying that calcite predominated in the aquifer. The mean $\mathrm{Mg}^{2+} / \mathrm{Ca}^{2+}$ activity ratio of the spring waters calculated by software speciation is 0.0405 , which correspond to a very low-Mg calcite having $\mathrm{Mg}^{2+} / \mathrm{Ca}^{2+}=0.000587$ applying the partition coefficient for $\mathrm{Mg}$ at $\mathrm{T}=8.1^{\circ} \mathrm{C}$ (Huang \& Fairchild, 2001). This probably corresponds to the composition of a secondary, poorly cristalline calcite in the local soil, in accord with the results obtained in other area (Sobecki \& Karathanasis, 1987).

Differently, water from soils and column tests are more scattered, with an higher $\mathrm{Ca}^{2+}$ concentration for the former (particularly for Gu-type soil samples) and a path converging toward the spring water's best fit for the latter (Fig. 7). As expected for a ground water circulating in a carbonate aquifer, thermodynamic calculations testified that the equilibrium was reached

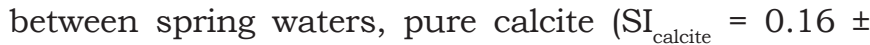
$0.20)$ and an ordered dolomite (SI dolomite-ord. $=0.009$ \pm 0.504). Soil waters showed increasing calcite saturation indexes from undersaturation (W-type $\mathrm{SI}_{\text {calcite }}=-1.69 \pm 1.28 ;$ Gnu-type $\mathrm{SI}_{\text {calcite }}=-0.89 \pm 1.28$ ) to a slight oversaturation (Gu-type $\mathrm{SI}_{\text {calcite }}=0.22 \pm$ 0.98); lower and more scattered values were obtained for dolomite $\left(\mathrm{W}\right.$-type $\mathrm{SI}_{\text {dolomite-ord. }}=-3.42 \pm 2.25$; Gnu-type $\mathrm{SI}_{\text {dolomite-ord. }}=-4.20 \pm 0.84 ; \mathrm{Gu}$-type $\mathrm{SI}_{\text {dolomite-ord. }}=-0.04 \pm$ 1.79). This statement is further supported by results of isotopic analyses. In fact, the $\delta^{13} \mathrm{C}_{\mathrm{DIC}}$ composition of infiltration water collected at the soil bottom in the study site (-15.77\%o VPDB; Petrella et al., 2009b) is very different from the composition of spring water (-11.51\%o VPDB; Petrella et al., 2009b). The calcium excess in soil waters showed in Fig. 7 may come from an interaction with clay minerals. In fact, in the $\left[\mathrm{Ca}^{2+}\right] /$ $\left[\mathrm{H}^{+}\right]^{2}$ and $\left[\mathrm{Mg}^{2+}\right] /\left[\mathrm{H}^{+}\right]^{2}$ mosaic activity diagram obtained from the water speciation, is showed that $\mathrm{G}_{\mathrm{nu}}$-type soil waters reached the stability kaolinite-montmorillonite stability limit, whereas the $\left[\mathrm{Ca}^{2+}\right] /\left[\mathrm{Mg}^{2+}\right]$ global ratios was buffered by calcite-dolomite equilibrium calculated for the mean $\log \mathrm{PCO}_{2}=-2.55$ of the springs (Fig. 8).

Finally, mean $\mathrm{NO}_{3}^{-}$concentrations are lower in spring water $(13 \mu \mathrm{eq} / 1)$ than in soil infiltration water (130 $\mu \mathrm{eq} / 1$ and $31 \mu \mathrm{eq} / 1$ during the first and the second infiltration events, respectively), and $\mathrm{NH}_{4}^{+}$is not detectable only in spring water. Conversely, $\mathrm{NO}_{2}^{-}$has the highest concentration in spring water (Fig. 5). These findings further support that denitrification, nitrate reduction and anammox processes are allowed by a microbial community within the aquifer system, according to previous suggestions.

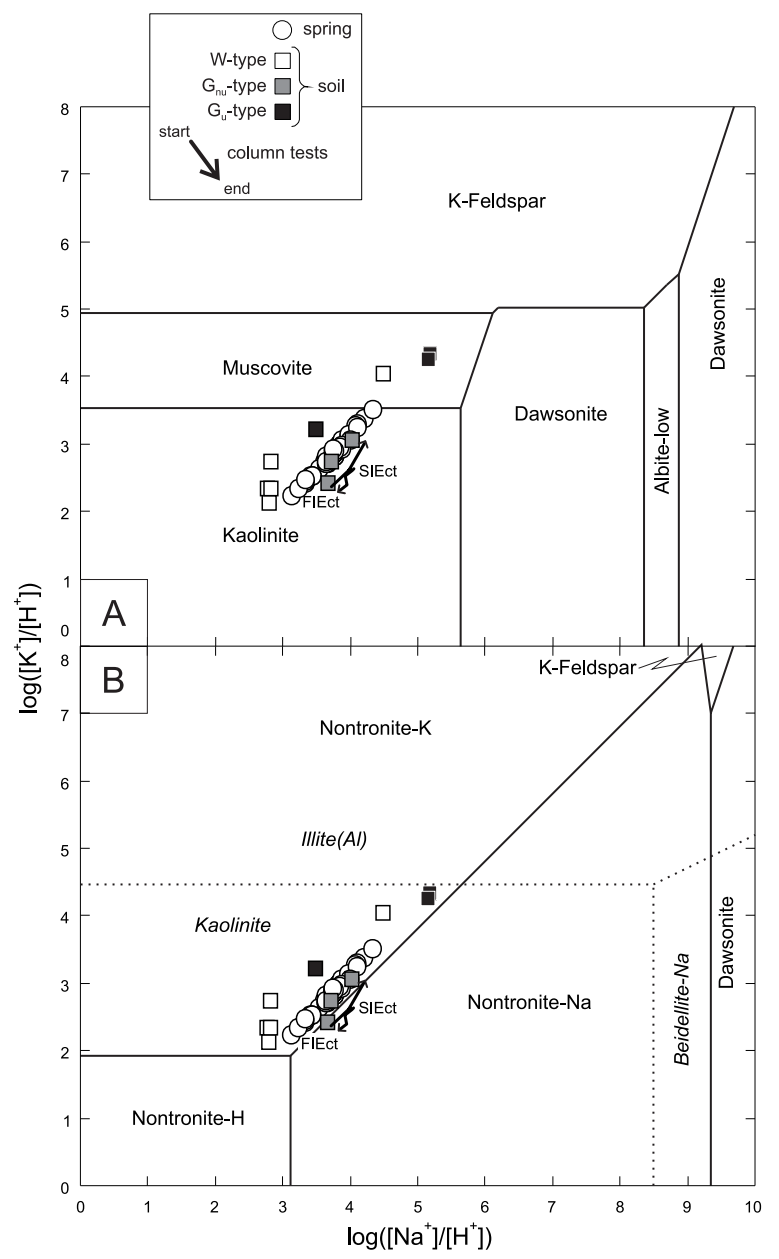

Fig. 6. Mosaic activity plot for the $\mathrm{K}_{2} \mathrm{O}-\mathrm{Na}_{2} \mathrm{O}-\mathrm{SiO}_{2}-\mathrm{Al}_{2} \mathrm{O}_{3}-\mathrm{CO}_{2}-\mathrm{H}_{2} \mathrm{O}$ system at $\mathrm{T}=8.1^{\circ} \mathrm{C}, \mathrm{P}=1.013$ bar. Dissolved silica and aluminium activity were buffered imposing $\log \left[\mathrm{SiO}_{2}\right]=-4.1$ (corresponding to a concentration of about $5 \mathrm{mg} / \mathrm{l}$ ) and kaolinite equilibrium, respectively; $\log \mathrm{PCO}_{2}=-2.55$ was also imposed according to the mean value obtained for the spring waters. Primary silicates as K-feldspar, muscovite and albite-low are shown in (A), whereas clay minerals in (B). Nontronites appeared when iron concentration was buffered with hematite or goethite. Solubility data were from thermo. com.v8.r6 (continuous line) and Thermoddem (dotted line and italic) thermodynamic datasets. FIEct and SIEct represent the first and second infiltration column test, respectively. 

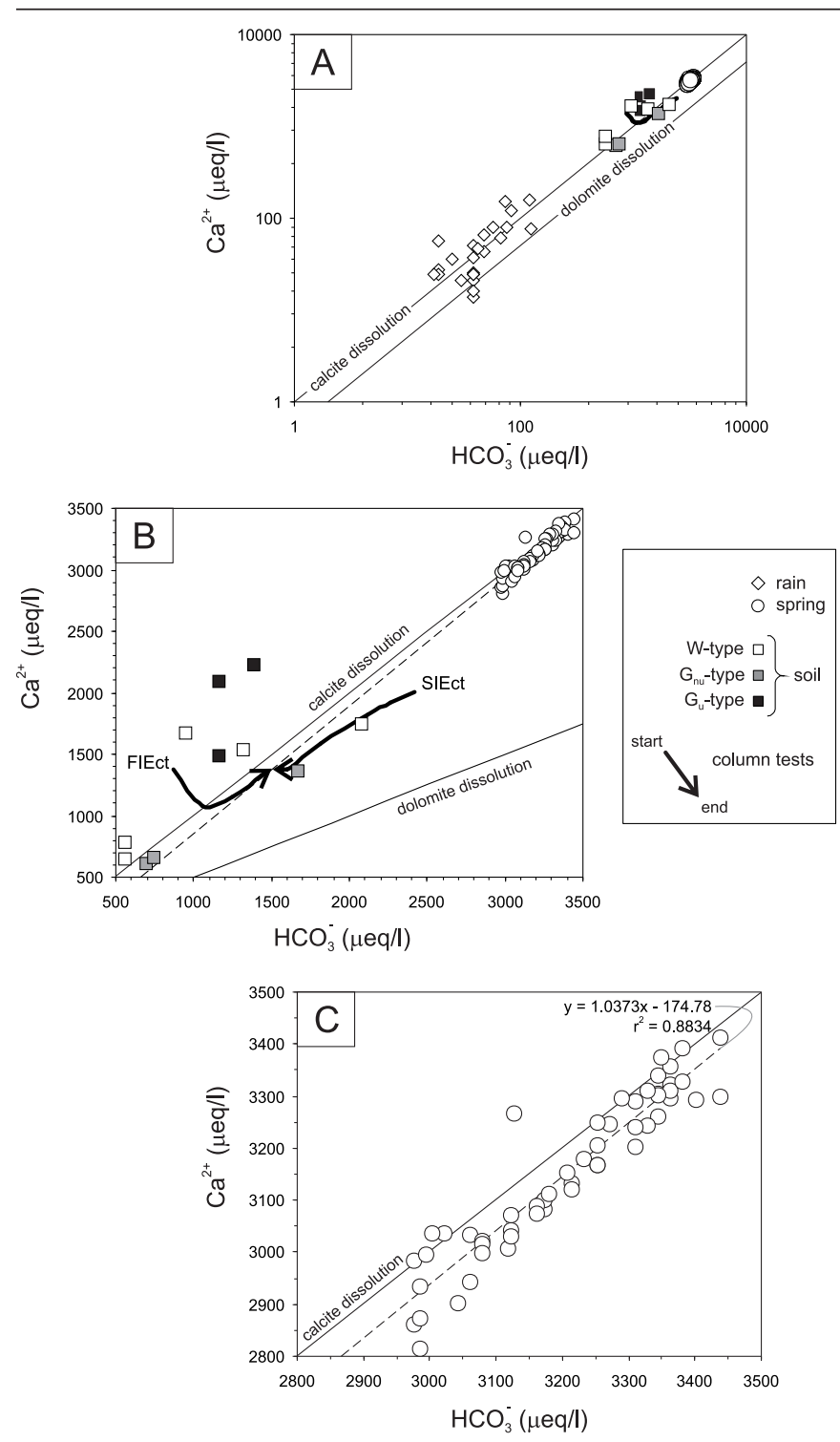

Fig. 7. Calcium vs bicarbonate concentration ( $\mu$ eq/l; logarithmic scale in A, linear scale in B and C) of rain, soil, spring water samples and soil infiltration waters during FIEct and SIEct, the first and second infiltration event, respectively. The lines represents calcite and dolomite dissolution (see text for details), whereas dashed line represents the calculated best-fit of the spring waters.

\section{CONCLUSIONS}

The studied soil has a great influence in modifying rainwater chemistry during percolation and then it is a factor of utmost importance when analysing the hydrochemistry of ground- and spring water at the experimental field site. This soil behaves as a set of different sources of chemical species. The most significant sources detected within this study are: (a) salts precipitated during the hotter periods of a hydrologic year, due to evaporation of rainwater in the soil, and (b) organic matter (including plant cells) which has a great influence on $\mathrm{K}^{+}$.

On the whole, about the $50 \%$ of the major ions $\mathrm{HCO}_{3}{ }^{-}$and $\mathrm{Ca}^{2+}$ in spring water is due to interaction between percolation water and soil medium, and another $50 \%$ is due to carbonate dissolution within the carbonate bedrock. However, several biogeochemical processes cause the concentration of such ions in soil infiltration water to significantly change over time, within a single rainwater event and between events.
Thus, the interaction between infiltration water and soil is a new factor to consider when analysing springs chemographs in carbonate environments within the Italian Apennine range. From the theoretically point of view, the influence of this phenomenon could be significant in those carbonate aquifers where rapid flow and low mixing occur, due to percolation and flow mostly concentrated in conduits. Conversely, this great variation of hydrochemistry in soil infiltration water should not significantly influence springs chemographs in carbonate aquifers similar to the tested one, because (a) the carbonate medium is essentially fractured and subordinately karstified, (b) no retention of percolation and water storage in temporary perched aquifers are observed, (c) no funnelling is observed in vertical shafts at the epikarst bottom, and (d) a significant mixing is expected in the fracture network (Celico et al., 2006; Petrella et al., 2007; Petrella et al., 2008). This topic will be thoroughly developed in a dedicated work, merging hydrochemical data with hydrogeological and isotopic data.

With regard to minor anions $\mathrm{Cl}^{-}$and $\mathrm{SO}_{4}{ }^{2-}$, the concentration in spring water is very close to that of infiltration water during short-term interaction with soil, but a decline is showed in the long-term. With regard to minor cations, $\mathrm{Mg}^{2+}$ concentrations in spring water are mostly (about the $80 \%$ ) due to interaction between underground water and carbonate rocks. Thus, it seems a good indicator of dynamics within the carbonate bedrock. In compartmentalized carbonate systems, such as the Acqua dei Faggi experimental site, the $\mathrm{Mg}^{2+} / \mathrm{Ca}^{2+}$ ratio could be tentatively used as indicator of interactions between compartments that are characterised by different percentage of dolostone within the carbonate sequence. The simultaneous equilibrium between spring water and carbonates (calcite and dolomite) may have produced the precipitation of poorly crystalline, very low-Mg calcites in the soil, with which percolating water may have reached equilibrium in turn. Differently, the concentrations of minor cations $\mathrm{Na}^{+}$and $\mathrm{K}^{+}$are greatly influenced by primary silicates (and probably plant cells for $\mathrm{K}^{+}$) particularly in the long period, whereas a buffering of their elemental ratios by clay minerals predominated in the short period.

Despite the soil is very rich in $\mathrm{NO}_{3}{ }^{-}$in wide areas, due to luxuriant vegetation, the concentrations of such anion in spring water are as low as those observed in the local rainwater. The results of this study suggest that this phenomenon is due to the existence of a soil microbial community that allows denitrification and nitrate reduction. Moreover, taking into consideration that infiltration processes cause anoxic conditions within the soil medium (demonstrated by production of acetate), the absence of $\mathrm{NH}_{4}^{+}$in spring water throughout the observation period should be due to anammox processes. A specific microbiological study is in progress to verify the effectiveness of such an hypothesis. Nitrate reduction could also explain the higher concentrations of $\mathrm{NO}_{2}^{-}$in spring water than in soil infiltration water (about the 200\%), despite the biological conversion of nitrite to dinitrogen gas during anammox processes. 


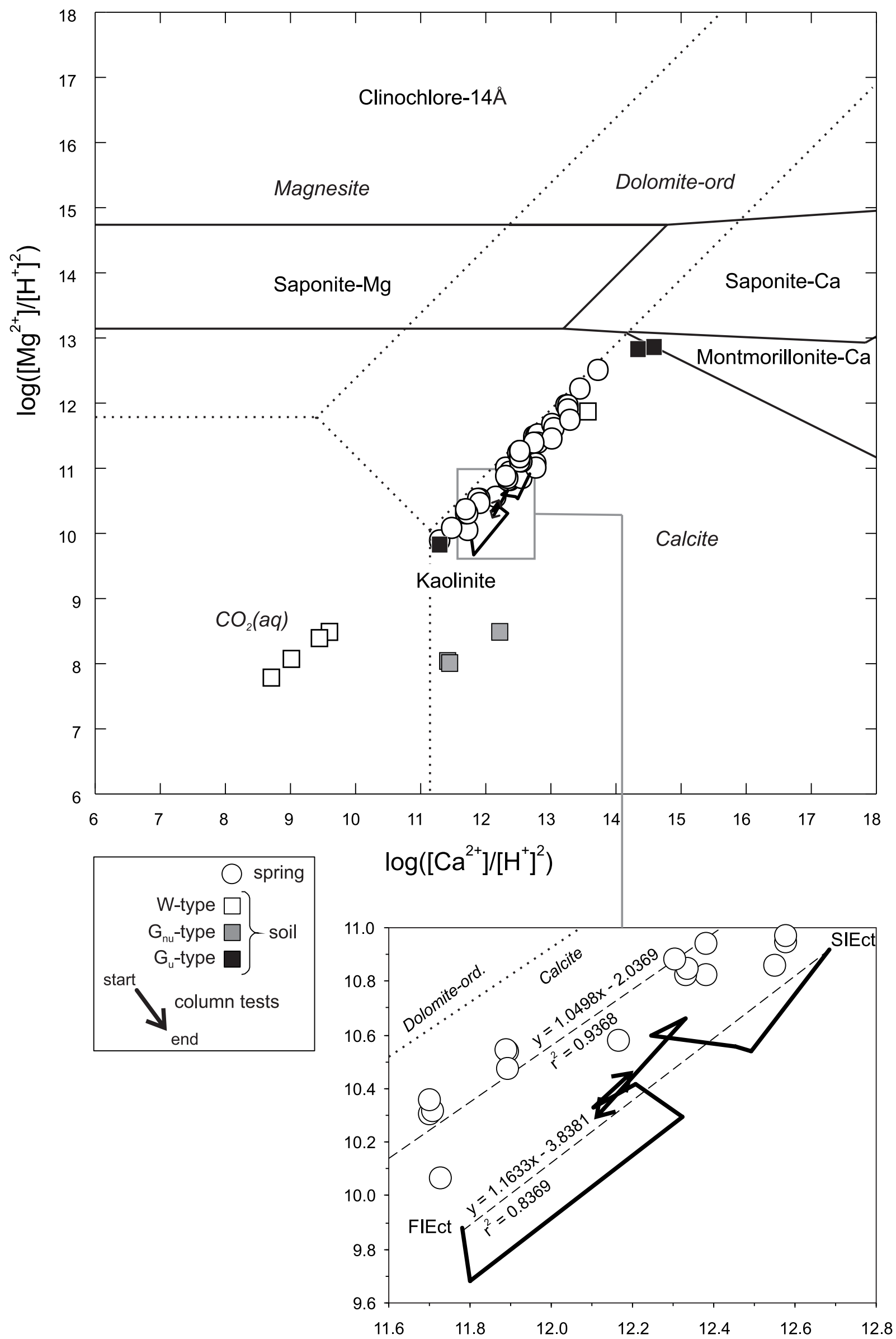

Fig. 8. Mosaic activity plot for the MgO-CaO-SiO $-\mathrm{Al}_{2} \mathrm{O}_{3}-\mathrm{CO}_{2}-\mathrm{H}_{2} \mathrm{O}$ system at $\mathrm{T}=8.1^{\circ} \mathrm{C}, \mathrm{P}=1.013$ bar. Dissolved silica and aluminium activity were buffered imposing $\log \left[\mathrm{SiO}_{2}\right]=-4.1$ (corresponding to a concentration of about $5 \mathrm{mg} / \mathrm{l}$ ) and kaolinite equilibrium, respectively. Dashed stability limits representing equilibrium between carbon-bearing phases (carbonate minerals and dissolved $\mathrm{CO}_{2}$; in italic) were obtained imposing logPCO $=-2.55$ according to the mean value obtained for the spring waters. A closer look to soil infiltration waters during FIEct and SIEct, the first and second infiltration event respectively, is also shown. 
In a broader context, these findings suggest that hydrochemistry and spring chemographs may be significantly influenced by several factors, such as relationships between soil and rainwater, vegetation, and microbial communities, which are not necessarily correlated with lithological and structural features of carbonate aquifers.

\section{ACKNOWLEDGEMENTS}

This work was supported by grants from the European Union (CC-WaterS programme) and the Ministero dell'Istruzione, dell'Università e della Ricerca (PRIN2008TL25YL).

\section{REFERENCES}

Allocca V., Celico F., Petrella E., Marzullo G. \& Naclerio G., 2008 - The role of land use and environmental factors on microbial pollution of mountainous limestone aquifers. Environmental Geology, 55: 277-283. http://dx.doi.org/10.1007/s00254-007-1002-5

Barbieri M., Boschetti T., Petitta M. \& Tallini M., 2005 Stable isotope $\left({ }^{2} \mathrm{H},{ }^{18} \mathrm{O}\right.$ and $\left.{ }^{87} \mathrm{Sr} /{ }^{86} \mathrm{Sr}\right)$ and hydrochemistry monitoring for groundwater hydrodynamics analysis in a karst aquifer (Gran Sasso, Central Italy). Applied Geochemistry, 20: 2063-2081. http://dx.doi.org/10.1016/j.apgeochem.2005.07.008

Bennetts D.A., Webb J.A., Stone D.J.M. \& Hill D.M., 2006 - Understanding the salinisation process for groundwater in an area of south-eastern Australia, using hydrochemical and isotopic evidence. Journal of Hydrology, 323: 178-192.

http://dx.doi.org/10.1016/j.jhydrol.2005.08.023

Bethke C.M. \& Yeakel S., 2008 - The Geochemist's Workbench Release 7.0-Essentials Guide. Hydrogeology Program, University of Illinois, Urbana, Illinois.

Blanc P., Lassin A. \& Piantone P., 2012 - THERMODDEM a database devoted to waste minerals. BRGM - Orléans, France.

Boschetti T., Toscani L., 2008 - Springs and streams of the Taro-Ceno Valley (Northern Apennine, Italy): Reaction path modeling of waters interacting with serpentinized ultramafic rocks. Chemical Geology, 76: 91-257.

${ }^{*}$ Celico F., Varcamonti M., Guida M. \& Naclerio G., 2004 - Influence of precipitation and soil on transport of fecal enterococci in fracture limestone aquifers. Applied and Environmental Microbiology, 70: 2843-2846.

http://dx.doi.org/10.1128/AEM.70.5.2843-2847.2004

Celico F., Petrella E. \& Celico P., 2006 - Hydrogeological behaviour of some fault zones in a carbonate aquifer of Southern Italy: an experimentally based model. Terra Nova, 18: 308-313.

http://dx.doi.org/10.1111/j.1365-3121.2006.00694.x

Celico F., Naclerio G., Bucci A., Nerone V., Capuano P., Carcione M., Allocca V. \& Celico P., 2010 - Influence of pyroclastic soil on epikarst formation: A test study in southern Italy. Terra Nova, 22: 110-115.

http://dx.doi.org/10.1111/j.1365-3121.2009.00923.x

Charlson R.J. \& Rodhe H., 1982 - Factors controlling the acidity of natural rain water. Nature, 295: 683-685. http://dx.doi.org/10.1038/295683a0

Cryer R., 1986 - Atmospheric solute inputs. In: Solute Processes, Trudgill ST (ed.), John Wiley, New York, USA.

Davidson E.A., Verchot L.V., Cattanio J.H., Ackerman I.L. \& Carvalho J.E.M., 2000 - Effects of soil water content on soil respiration in forests and cattle pastures of eastern Amazonia. Biogeochemistry, 48: 53-69. http://dx.doi.org/10.1023/A:1006204113917 de Mello W.Z., 2001 - Precipitation chemistry in the coast of the metropolitan region of Rio de Janeiro, Brazil. Environmental Pollution, 114: 235-242.

http://dx.doi.org/10.1016/S0269-7491(00)00209-8

Edwards M.D. \& Webb J.A., 2006 - Influence of soil processes on groundwater composition, southeastern Australia. Geochimica et Cosmochimica Acta, 70: A154-A162. http://dx.doi.org/10.1016/j.gca.2006.06.1375

Eswaran H., Van Den Berg E. \& Reich P., 1993 - Organic carbon in soils of the world. Soil Science Society of America Journal, 57: 192-194.

http://dx.doi.org/10.2136/ sssaj1993.03615995005700010034x

Evans H.J. \& Sorger G.J., 1966 - Role of mineral elements with emphasis on the univalent cations. Annual Review of Plant Physiology, 17: 47-76.

http://dx.doi.org/10.1146/annurev.pp.17.060166.000403

FAO, 1988. Soil Map of the World, Revised Legend, Reprinted with corrections, World Soil Resources Report, 60, Roma, Italy.

Ghiglione J.F., Philippot L., Philippe N., Lensi R. \& Potier P., 1999 - Disruption of narG, the gene encoding the catalytic subunit of respiratory nitrate reductase, also affects nitrite respiration in Pseudomonas fluorescens YT101. Journal of Bacteriology, 181: 5099-5102.

Golobočanin D., Žujić A., Milenković A., Miljević N., 2008 - Precipitation composition and wet deposition temporal pattern in Central Serbia for the period from 1998 to 2004. Environmental Monitoring and Assessment, 142: 185-198. http://dx.doi.org/10.1007/s10661-007-9919-4

Herut B., Starinsky A., Katz A. \& Rosenfeld D., 2000 - Relationship between the acidity and chemical composition of rainwater and climatological conditions along a transition zone between large deserts and Mediterranean climate, Israel. Atmospheric Environment, 34: 1281-1292.

http://dx.doi.org/10.1016/S1352-2310(99)00291-5

Howard D.M. \& Howard P.J.A., 1993 - Relationships between $\mathrm{CO}_{2}$ evolution, moisture content and temperature for a range of soil types. Soil Biology and Biochemistry, 25: 1537-1546.

http://dx.doi.org/10.1016/0038-0717(93)90008-Y

Katou H., 2004 - Determining competitive nitrate and chloride adsorption in an andisol by the unsaturated transient flow method. Soil Science and Plant Nutrition, 50: 119-127.

http://dx.doi.org/10.1080/00380768.2004.10408459

Kulshrestha U.C., Sarkar A.K., Srivastava S.S. \& Parashar D.C., 1996 - Investigation into atmospheric deposition through precipitation studies at New Delhi (India). Atmospheric Environment, 30: 4149-4154. http://dx.doi.org/10.1016/1352-2310(96)00034-9

Kulshrestha U.C., Kulshrestha M.J., Sekar R., Sastry G.S.R. \& Vairamani M., 2003 - Chemical characteristics of rainwater at an urban site of south-cantral India. Atmospheric Environment, 37: 3019-3026. http://dx.doi.org/10.1016/S1352-2310(03)00266-8

Küsel K. \& Drake H.L., 1995 - Effects of environmental parameters on the formation and turnover of acetate by forest soils. Applied and Environmental Microbiology, 61: 3667-3675.

Küsel K. \& Drake H.L., 1996 - Anaerobic capacities of leaf litter. Applied and Environmental Microbiology, 62: 4216-4219.

KüselK. \&DrakeH.L., 1999-Microbialturnoveroflowmolecular weight organic acids during leaf litter decomposition. Soil Biology and Biochemistry, 31: 107-118.

http://dx.doi.org/10.1016/S0038-0717(98)00111-4 
Küsel K., Wagner C., Trinkwalter T., Gößner A.S., Baumler R. \& Drake H.L., 2002 - Microbial reduction of $\mathrm{Fe}(\mathrm{III})$ and turnover of acetate in Hawaiian soils. FEMS Microbiology Ecology, 40: 73-81. http://dx.doi.org/10.1111/j.1574-6941.2002.tb00938.x

Kuypers M.M.M., Sliekers A.O., Lavik G., Schmid M., Jørgensen B.B., Kuenen J.G., Sinninghe Damsté J.S., Strous M. \& Jetten M.S.M., 2003 - Anaerobic ammonium oxidation by anammox bacteria in the Black Sea. Nature, 422: 608-611.

http://dx.doi.org/10.1038/nature01472

Lee C. \& Wakeham S.G., 1989 - Organic matter in sea-water: biogeochemical processes. In: Chemical Oceanography, Riley JP (ed.), Academic Press, London, UK.

Linn D.M. \& Doran J.W., 1984 - Effect of water-filled pore space on carbon dioxide and nitrous oxide production in tilled and nontilled soils. Soil Science Society of America Journal, 48: 1267-1272. http://dx.doi.org/10.2136/ sssaj1984.03615995004800060013x

Meijer A., 2002 - Conceptual model of the controls on natural water chemistry at Yucca Mountain, Nevada. Applied Geochemistry, 17: 793-805.

http://dx.doi.org/10.1016/S0883-2927(02)00039-2

Migliavacca D., Teixeira E.C., Wiegand F., Machado A.C.M. \& Sanchez J., 2005 - Atmospheric precipitation and chemical composition of an urban site, Guaiba hydrographic basin, Brazil. Atmospheric Environment, 39: 1829-1844.

http://dx.doi.org/10.1016/j.atmosenv.2004.12.005

Musgrove M. \& Banner J.L., 2004 - Controls on spatial and temporal variability of vadose dripwater geochemistry: Edwards Aquifer, central Texas. Geochimica et Cosmochimica Acta, 68: 1007-1020.

http://dx.doi.org/10.1016/j.gca.2003.08.014

Naclerio G., Petrella E., Nerone V., Allocca V., De Vita P. \& Celico F., 2008 - Influence of topsoil of pyroclastic origin on microbial contamination of groundwater in fractured carbonate aquifers. Hydrogeology Journal, 16: 10571064. http://dx.doi.org/10.1007/s10040-008-0297-y

Naclerio G., Fardella G., Marzullo G. \& Celico F., 2009a - Filtration of Bacillus subtilis and Bacillus cereus spores in a pyroclastic topsoil, carbonate Apennines, southern Italy. Colloids and Surfaces B: Biointerfaces, 70: 25-28. http://dx.doi.org/10.1016/j.colsurfb.2008.12.009

Naclerio G., Nerone V., Bucci A., Allocca V. \& Celico F., $2009 \mathrm{~b}$ - Role of organic matter and clay fraction on migration of Escherichia coli cells through pyroclastic soils, southern Italy. Colloids and Surfaces B: Biointerfaces, 72: 57-61.

http://dx.doi.org/10.1016/j.colsurfb.2009.03.009

Ndala S.M., Scholes M.C. \& Fey M.V., 2006 - Soil properties and processes driving the leaching of nitrate in the forested catchments of the eastern escarpment of South Africa. Forest Ecology and Management, 236: 142-152. http://dx.doi.org/10.1016/j.foreco.2006.08.001

Orchard V.A. \& Cook F., 1983 - Relationship between soil respiration and soil moisture. Soil Biology and Biochemistry 15: 447-453.

http://dx.doi.org/10.1016/0038-0717(83)90010-X

Parkhurst D.L. \& Appelo C.A.J., 1999 - User's guide to PHREEQC (version 2)-a computer program for speciation, batch-reaction, one-dimensional transport, and inverse geochemical calculations. Water-Resources Investigation Report, US Geological Survey 99-4259.

Penton C.R., Devol A.H. \& Tiedje J.M., 2006 - Molecular evidence for the broad distribution of anaerobic ammonium-oxidizing bacteria in freshwater and marine sediments. Applied and Environmental Microbiology, 72: 6829-6832.

http://dx.doi.org/10.1128/AEM.01254-06
Pescatore T., 1963 - Rapporti tra depressione molisanosannitica e Appennino calcareo. Bollettino della Società dei Naturalisti in Napoli, 72: 213-225.

Petrella E. \& Celico F., 2013 - Mixing of water in a carbonate aquifer, southern Italy, analysed through stable isotope investigations. International Journal of Speleology, 42: 25-33.

http://dx.doi.org/10.5038/1827-806X.42.1.4

Petrella E., Capuano P. \& Celico F., 2007 - Unusual behaviour of epikarst in the Acqua dei Faggi carbonate aquifer (Southern Italy). Terra Nova, 19: 82-88. http://dx.doi.org/10.1111/j.1365-3121.2006.00720.x

Petrella E., Falasca A. \& Celico F., 2008 - Natural-gradient tracer experiments in epikarst: a test study in the Acqua dei Faggi experimental site, southern Italy. Geofluids, 8: 159-166.

http://dx.doi.org/10.1111/j.1468-8123.2008.00214.x

Petrella E., Capuano P., Carcione M. \& Celico F., 2009a A high-altitude temporary spring in a compartmentalized carbonate aquifer: the role of low-permeability faults and karst conduits. Hydrological Processes, 23: 3354-3364. http://dx.doi.org/10.1002/hyp.7454

Petrella E., Naclerio G., Falasca A., Bucci A., Capuano P., De Felice V. \& Celico F., 2009b - Non-permanent shallow halocline in a fractured carbonate aquifer, southern Italy. Journal of Hydrology, 373: 267-272. http://dx.doi.org/10.1016/j.jhydrol.2009.04.033

Philippot L., 2005 - Tracking nitrate reducers and denitrifiers in the environment. Biochemical Society Transactions, 33: 200-204. http:/ / dx.doi.org/10.1042/BST0330200

Pigna M., Jara A.A., Mora M.L. \& Violante A., 2007 - Effect of $\mathrm{pH}$, phosphate and/or malate on sulfate sorption on andisols. Journal of Soil Science and Plant Nutrition 7: 662-673.

Raich J.W. \& Schlesinger W.H., 1992 - The global carbon dioxide flux in soil respiration and its relationship to vegetation and climate. Tellus, 44b: 81-99. http://dx.doi.org/10.1034/j.1600-0889.1992.t01-1-00001.x

Risk D., Kellman L. \& Beltrami H., 2002 - Carbon dioxide in soil profiles: production and temperature dependence. Geophysical Research Letters, 29: 1-4.

http://dx.doi.org/10.1029/2001GL014002

Schulze-Makuch D., 2005 - Longitudinal dispersivity data and implications for scaling behavior. Ground Water, 43: 443-456.

http://dx.doi.org/10.1111/j.1745-6584.2005.0051.x

Scott A.D. \& Smith S.J., 1966 - Susceptibility of interlayer potassium in micas to exchange with sodium. In: Proceedings of the 14th National Conference on Clays and Clay Minerals, Pergamon Press. London, UK: 69-81. http://dx.doi.org/10.1016/B978-0-08-011908-3.50008-6

Sobecki T.M. \& Karathanasis A.D., 1987 Quantification and compositional characterization of pedogenic calcite and dolomite in calcic horizons of selected aquolls. Soil Science Society of America Journal, 51: 683-690. http://dx.doi.org/10.2136/ sssaj1987.03615995005100030024x

Strous M., Fuerst J.A., Kramer E.H., Logemann S., Muyzer G., van de Pas-Schoonen K.T., Webb R., Kuenen J.G. \& Jetten M.S., 1999 - Missing lithotroph identified as new planctomycete. Nature, 400: 446-449. http://dx.doi.org/10.1038/22749

Tooth A.F. \& Fairchild I.J., 2003 - Soil and karst aquifer hydrological controls on the geochemical evolution of speleothem-forming drip waters, Crag Cave, southwest Ireland. Journal of Hydrology, 273: 51-68. http://dx.doi.org/10.1016/S0022-1694(02)00349-9

USDA, 1979 - Soil Conservation Service. Engineering Field Manual, USDA, USA.

Verbaendert I., De Vos P., Boon N. \& Heylen K., 2011 - Denitrification in Gram-positive bacteria: an underexplored trait. Biochemical Society Transactions, 39: 254-258. http://dx.doi.org/10.1042/BST0390254 
Wagner C., Grießhammer A. \& Drake H.L., 1996 Acetogenic capacities and the anaerobic turnover of carbon in a Kansas prairie soil. Applied and Environmental Microbiology, 62: 494-500.
Wang G. \& Skipper H.D., 2004-Identification ofdenitrifying rhizobacteria from bentgrass and bermudagrass golf greens. Journal of Applied Microbiology, 97: 827-837. http://dx.doi.org/10.1111/j.1365-2672.2004.02368.x 